\title{
Presettlement forest in southern Ontario: Ecosystems measured through a cultural prism ${ }^{1}$
}

\author{
by Roger Suffling ${ }^{2}$, Michael Evans ${ }^{2}$ and Ajith Perera ${ }^{3}$
}

To better manage southern Ontario's natural forests, the former and present status of old growth must be understood. We hypothesize that old-growth pine (Pinus spp.), although dominant elsewhere, was less common in southern Ontario than popular history suggests: we are obliged to evaluate historical information that has been filtered both by the original compilers and through our own biases. Beginning around $600 \mathrm{AD}$, the predominant beech (Fagus americana) forest was partially replaced by maple (primarily Acer saccharum), oaks (Quercus spp.) and eastern white pine (P. strobus). This pine increase either followed abandonment of pre-Columbian agriculture or, more plausibly, accompanied climate cooling. Eighteenth and $19^{\text {th }}$ century European settlers encountered abundant large trees, which they hewed for square pine timber, milled timber, and tanbark. Other stands were cut and burned for agricultural clearance, with a potash by-product. Until recently, Ontario research emphasized the old-growth pine stands of central and northern Ontario to the relative exclusion of other kinds of old forest because very few southern Ontario old-growth stands remained to study. Ontario forest resource inventory data (FRI) show stands of over 150 years totalling only 1475 ha in 1978, concentrated on the Oak Ridges Moraine, the St. Lawrence Valley and the Awenda Peninsula. Red (P. resinosa) and eastern white pine stands constituted only $5.3 \%$ of the 1978 forested area, with virtually none of over 150 years, whereas eastern hemlock (Tsuga canadensis) stands constituted $12.8 \%$. The difficulty in finding modern old growth necessitates historical reconstruction using physical, written and graphical resources, including early survey records and trade statistics. In a case study of 1822 survey data from Darling Township (Lanark Co.) and 1960 FRI, vegetation was classified using TWINSPAN and mapped using ARC/INFO Thiessen polygons. In 1822, dominant hemlock occupied half the township but it has since been eliminated as a dominant. Conversely, there were no pine-dominated forests in 1822 , but these had increased to $16 \%$ of the area by 1960. A second case used similar methods, with 1855 data for St. Edmunds and Lindsay townships (Bruce Co.) and 1981 FRI. Although logging halved the area and reduced the stature of pines in the large pinery, the elimination of dominant hemlock (originally $41 \%$ by area) is more significant. Fragmentary square timber trade data suggest that at least half the large pines in Bruce County were in St. Edmunds, so pine must have been spectacularly concentrated in a few areas. The third case, a map constructed from Gourlay's 1817-1819 survey, also demonstrates that pine-dominated areas were in the minority in southern Ontario, concentrated on sandy soils around Lakes Ontario and Erie. However, big hemlocks, beeches, maples and oaks were much more common overall. Management responses to this information should include designation of older southern Ontario forest stands (especially those never cleared since settlement) for maturation into an old-growth state, and the systematic restoration of eastern hemlock and beech stands for conservation purposes in southern Ontario.

Key words: old-growth forest, Canada, Ontario, historical ecology, forest history

Afin de mieux aménager les forêts naturelles du Sud de l'Ontario, il faut comprendre qu'elle a été et qu'elle est la situation des vieilles forêts. Nous posons l'hypothèse que la vieille pinède (Pinus spp.), bien que dominante ailleurs, était moins commune dans le Sud de l'Ontario que ne le laisse croire l'histoire populaire : nous sommes donc obligés d'évaluer l'information historique à travers le filtre des premières compilations et de nos propres partis pris. À compter d'environ 600 après J.-C., la forêt prédominante de hêtres (Fagus americana) a été partiellement remplacée par des érables (principalement Acer saccharum), des chênes (Quercus spp.) et le pin blanc $(P$. strobus). Cette progression du pin a soit suivi l'abandon de l'agriculture précolombienne, soit, ce qui est plus plausible, coïncidé avec un refroidissement climatique. Les colons européens des XVIII ${ }^{\mathrm{e}}$ et XIX ${ }^{\mathrm{e}}$ siècles ont trouvé une abondance de gros pins, qu'ils ont abattus et dont ils ont tiré des équarris, du bois ouvré et du tan. Par le fer et le feu, d'autres peuplements ont fait place à l'agriculture, la potasse étant un sous-produit de l'opération encore recemment, la recherche ontarienne privilégiait les vieilles pinèdes du Centre et du Nord de l'Ontario, aux dépens des autres types de vieilles forêts, parce qu'il subsistait très peu de vieux peuplements à étudier dans le Sud de l'Ontario. Les inventaires des ressources forestières (IRF) de l'Ontario montrent que les peuplements de plus de 150 ans, qui ne totalisaient que 1475 ha en 1978, se trouvaient principalement sur la moraine d'Oak Ridges, dans la vallée du Saint-Laurent et dans la péninsule d'Awenda. Les peuplements de pins rouges ( $P$. resinosa) et de pins blancs ne constituaient que 5,3\% de la superficie forestière en 1978, et presque aucun de ces arbres n'avait plus de 150 ans, tandis que les peuplements de pruches du Canada (Tsuga canadensis) en constituaient $12,8 \%$. La rareté des vieilles forêts actuelles exige une reconstruction historique à partir de documents physiques, écrits et graphiques notamment des premiers inventaires et des premières statistiques commerciales. Ainsi, dans l'étude des données de l'inventaire de 1822 dans le canton de Darling (comté de Lanark) et de l'IRF de 1960, on a classé la végétation à l'aide de TWINSPAN et on l'a cartographiée à l'aide de polygones de Thiessen produits par le logiciel ARC/INFO. En 1822, la pruche, dominante, occupait la moitié du canton, mais, depuis, elle a cessé d'être dominante. Réciproquement, en 1822, le pin ne dominait dans aucune forêt, mais, en 1960, cette essence occupait $16 \%$ de la superficie. Une deuxième étude, au moyen de méthodes semblables, a porté sur les données de 1855, pour les cantons de St. Edmunds et de Lindsay, compté de Bruce, et sur l'IRF de 1981. Bien que la coupe forestière eût réduit de moitié la vaste pinède et réduit la stature de ses pins, l'élimination de la pruche dominante (à l'origine $41 \%$ de la superficie) est plus significative. Les données fragmentaires sur le commerce des équarris portent à croire qu'au moins la moitié des gros pins du comté de Bruce se trouvaient dans le canton de St. Edmunds, de sorte que le pin doit avoir constitué des peuplements d'une pureté spectaculaire dans quelques localités peu nombreuses. Le troisième cas, une carte établie à partir de l'inventaire de Gourlay de 1817-1819, montre aussi que les superficies où le pin dominait étaient la minorité dans le Sud de l'Ontario, qu'elles

\footnotetext{
${ }^{1}$ Paper presented at the "Old-growth Forests in Canada: A Science Perspective" Conference, October 14-19, 2001, Sault Ste. Marie, ON

${ }^{2}$ Faculty of Environmental Studies, University of Waterloo, Waterloo, Ontario N2L 3G1. E-mail: rcsuffli@ fes.uwaterloo.ca

${ }^{3}$ Ontario Forest Research Institute, 1235 Queen St. E., Sault Ste. Marie, Ontario P6A 2E5. E-mail: ajith.perera@mnr.gov.on.ca
} 
étaient plus abondantes sur les sols sablonneux entourant les lacs Ontario et Érié. Cependant, les pruches, les hêtres, les érables et les chênes géants étaient beaucoup plus communs globalement. À la lumière de ces données, les aménagistes devraient notamment désigner les vieux peuplements forestiers du Sud de l'Ontario (plus particulièrement ceux qui n'ont jamais été soumis à une coupe d'éclaircie depuis la colonisation), pour qu'ils puissent évoluer en vieilles forêts, et restaurer systématiquement les peuplements de pruches du Canada et de hêtres du Sud de l'Ontario, pour les conserver.

Mots clés : vieille forêt, Canada, Ontario, écologie historique, histoire des forêts

\section{Introduction and \\ Definitions}

People are rapidly modifying or eliminating old-growth forests worldwide (Bryant 1997). This trend is starkly evident in Canada, and has focused concerns in Ontario (Anonymous 1990) on the old pine forests of central Ontario. For example, Ellis (1993) tallied how much old-growth remains in Canada and noted mostly pine sites in Ontario, but

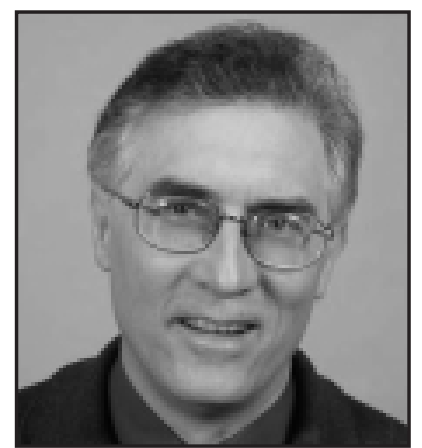

Roger Suffling

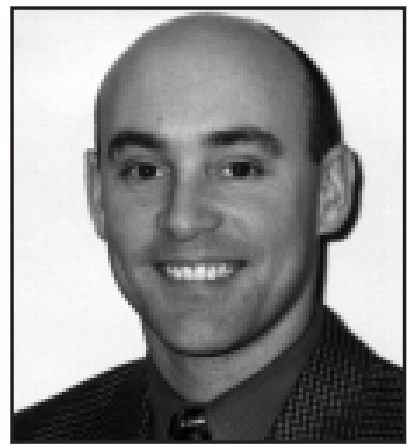

Michael Evans

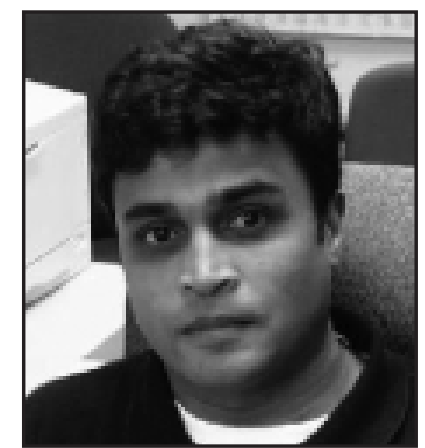

Ajith Perera only one non-pine site, in southern Ontario (Backus Woods). Similarly, the Ontario Old Growth Policy Advisory Committee devoted almost all its attention to red (Pinus resinosa) and white pine (P. strobus) areas in the centre of the province (Kidd 1993, Anonymous 1994). This emphasis on central Ontario old-growth pine forests is engendered by their continued, current disappearance through logging. This focus, and the popular historical mythology of square-timber pine logging, tend to leave the impression that what has been lost in southern Ontario was primarily an old-growth pine system, but Larson et al. (1999) have balanced some of this attention on northern pines, through their review of heritage forests in southern Ontario.

To manage these southern remnants, we need to know what kinds and quantities of forests existed before the presettlement forest was cleared. This complements other ways of understanding the natural potential for old growth, such as quantitative predictions as a function of geoclimatic conditions, disturbance, and species biology. However, determining oldgrowth potential from historical information is difficult in southern Ontario and similar regions, where almost all old growth has long been eliminated. Researchers look to historical records to glimpse what has been lost, but we view history through a cultural prism created by others, and it can distort what we see. For effective historical interpretation, we must understand the frequently limited range of experience of the administrators, surveyors, writers and artists that focused and filtered their materials. Likewise, we must recognize how our own experiences and biases potentially affect interpretation of the recorded information.

Our focus is on old pine forests and the role of pine in other old-growth forests in southern Ontario at the time of European settlement. By southern Ontario, we mean that part of the province lying south of the Precambrian Shield, although one case study lies on the edge of the Shield. Fig. 1 identifies places and features mentioned in the text. Although the observations are specific to southern Ontario, some findings apply broadly to deciduous forest and the Great Lakes forest biome landscapes in southern Quebec, western New York State and Michigan.
Old-growth forest has been defined in an Ontario context as “... ecosystems characterized by the presence of old trees with their associated plants, animals and ecological processes" and they are characterized as "reflective of presettlement forest" (Kidd 1993). As incomplete historical records prevent identification of old growth using strict definitions, we shall call this imprecisely identified vegetation "mature forest" or "old forest" and it roughly corresponds to Leverett's (1996) Category 2 and 3 definitions of old growth (i.e., probably older than 150 years, it "looks old," and understorey initiation has probably begun). By "old growth," we mean a formally defined condition as in Kidd (1993), Anonymous (1994) and, especially, Leverett's (1996) Category 1 definition (50\% of trees more than half the average life span for the species in question, some trees near maximum life span, no cutting or planting of alien species, presence of late-successional species, nature-managed stand structure, minimum of 2-4 ha, and annual net increment in biomass near zero). The characteristic features of oldgrowth forest in southern Ontario have also been summarized in Anonymous (1996). By "original" ecosystems, we mean those existing at the date of first European settlement, and this year varies across the province. For brevity, "settlement" refers to European settlement. Ecosystems encountered by European explorers and settlers had been modified to various extents by native peoples over long periods, so we make no $a$ priori assumption that these landscapes are entirely natural in origin. However, this was probably so for most ecosystems in most places.

\section{Historical Context}

Bennett (1987), Ritchie (1987), Day (1990) and Larson et al. (1999) have summarized the literature on the pre-history of southern Ontario forests, beginning with the last deglaciation. Post-glacial tundra gave way to a sequence of forest colonization, with poplar (Populus) dominant, followed by spruce (Picea spp.), jack (Pinus banksiana) and red pine (P. resinosa), and then eastern white pine (P. strobus). By $9000 \mathrm{BP}$, most of 


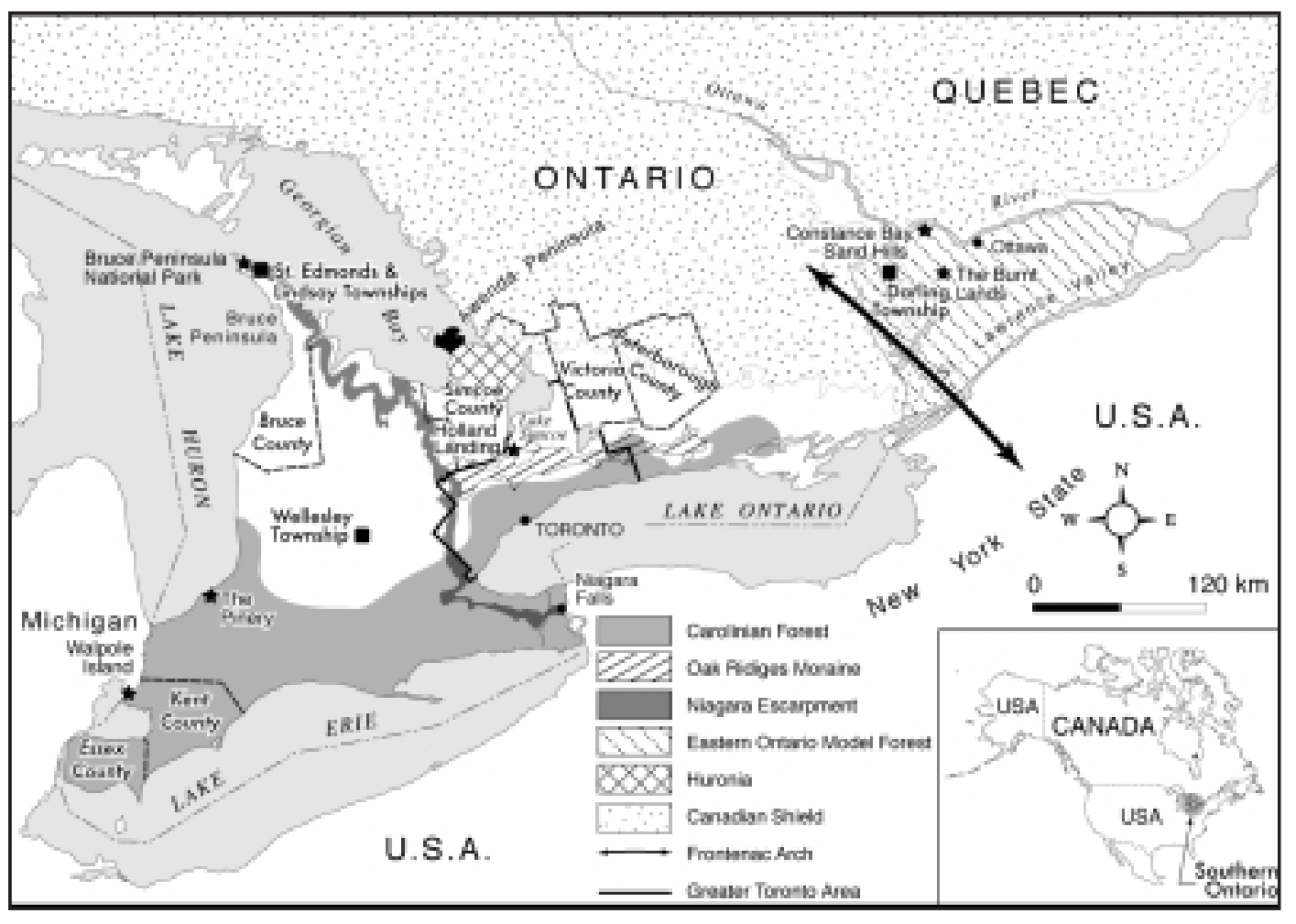

Fig. 1. Southern Ontario, showing places and features mentioned in the text.

the modern tree species of southern Ontario were in place. The hypsithermal of 8000-5000 BP peaked around 5500 years BP (McAndrews 1994), with slightly higher temperatures than now prevailing and oak (Quercus spp.) savanna established widely north of Lake Erie in 6000-4000 BP (Szeicz and Macdonald 1991). In the cooler period after $5000 \mathrm{BP}$, hemlock (Tsuga canadensis) and later beech (Fagus americana) were dominant, but at about $1400 \mathrm{AD}$, beech declined and was replaced by sugar maple (Acer saccharum), oaks and eastern white pine in the Toronto region at least. Delcourt and Delcourt (1987) have mapped these trends on a continental scale, showing the gradual northward movement of various taxa in the era following the most recent deglaciation.

Sparse populations of hunter-gatherer peoples had been present in southern Ontario since soon after the last ice age. However, beginning about $600 \mathrm{AD}$, a major land-use change occurred with the adoption of corn/bean/squash agriculture by Iroquoian groups. It was a swiddening (cleared by burning), shifting agriculture that required periodic relocation of villages to avoid soil exhaustion and weed infestation (Snow 1994). The culture of these crops had spread north from Central America, inducing more sedentary economies, more inter-tribal warfare, and more organized government. This agricultural expansion had been occurring with the Iroquois, the Huron and other tribes in what was to be Ontario just before the first European contact (Hasenstab 1990, Snow 1994). Even so, other cultures such as the Algonquians and Chippewas (Ojibwas) still relied on hunting and gathering.

The advent of shifting agriculture, with its increased forest disturbance, has been used to explain the replacement of beech by oak and then pine during the period from 1400 to 1800 (Burdon et al. 1986, McAndrews 1988, McAndrews and Boyko-Diakonow 1989). Davis et al. (1996) discussed simi- lar patterns in northern Michigan. However, Campbell and McAndrews (1993) subsequently argued that these changes are also evident in areas unaffected by aboriginal farming and actually reflect Little Ice Age cooling (ca. 1200-1850).

Beginning in 1615, and consistently from 1625, French Jesuit missionaries were active in Ontario, especially at the south end of Georgian Bay with its concentration of agricultural Huron villages. European diseases that were new and virulent to indigenous peoples destroyed more than half the Huron population during 1634-1639 and similar epidemics devastated other woodland Indian cultures in other regions (Snow 1994). The Iroquois, avenging a Huron and French incursion of 1609, exploited this weakness to attack them in the 1640s, and many Huron survivors then withdrew to Quebec (Cooper 1978), leaving agricultural areas to forest encroachment. Subsequent European settlers encountered the second-growth forest that had sprung up in such areas. Heidenreich $(1970,1973)$ described these changes in Huronia using 1820-1821 survey records, and the predominance of pine at that time is striking.

The European forest clearance of Ontario has been summarized by Head (1975). Empire Loyalists fleeing the American Revolution in the 1780s were the first non-native immigrants. They settled the north shores of Lakes Ontario and Erie and along the St. Lawrence Valley and, although they were most interested in clearing fertile land for agriculture, they also engaged in logging. These and subsequent tides of immigrants from the British Isles, and later from other nations, cleared the forest from the lower Great Lakes shorelines in a broadly northern direction, first in the Carolinian forest, then in the Great Lakes forest biome. Dates of first land surveys are mapped in Gentilcore and Donkin (1973). Complete clearance was inhibited by political factors (Gourlay 1974) that only dissipated with the reforms following the 1837 rebellion. 
The land clearance pattern was moulded partly by the cultures of the settlers, but more so by economic and ecological goals, opportunities and constraints. On fertile soils, the focus was on agriculture and on very fertile soils, land clearance was almost complete (e.g., Kent and Essex Counties). However, in most areas woodlots were retained by custom and by law for production of vital firewood, structural timber and maple syrup.

In other regions, governments, land companies and many pioneers failed to recognize or ignored the severe limitations of poor soils. The same settlement pattern occurred, but was followed by soil exhaustion and erosion, farm abandonment and subsequent reforestation (e.g., Norfolk County). In other areas, ostensible settlement was really a logging operation, with occupants moving on after they had high-graded the most profitable timber. These loggers often sold land to gullible settlers who were obliged to destroy the woods and the soil, and abandon their properties when they no longer yielded even a meagre living (northern Bruce and Grey Counties exemplify this pattern).

In still other areas, generally in the late 19th and early $20^{\text {th }}$ centuries, and further north on the Precambrian Shield, large companies, such as J.R. Booth, logged the forest, taking mostly large timber that would float down the rivers. This trade has often been thought of as predominantly in white and red pine. Square-timber logging of pines has spawned a deeply imbedded folk memory that defines and stereotypes Canadian culture nationally, as shown in Tom Thompson's paintings and, internationally, in the scurrilous Monty Python lumberjack skit (McCall 1991). In particular, many literary descriptions mention the tall pines. For example, Frances Simpson, wife of a Hudson's Bay Company governor, wrote of the Ottawa River in 1830:

"The Country on either side a thick Forest; the trees near the edge of the Water low, and branching, chiefly Aspen; while those behind were Pine, straight as Arrows, and growing to an enormous height: everything was calm and quiet..." (as quoted in Wake 1997).

The stereotypical tradition that grew up was reinforced and ingrained by generations of school textbooks, such as Braithwaite and Lambert (1957).

Regardless of logging and clearance style, the tendency in any region where timber could be marketed was to extract large trees first. In these landscapes, which were initially devoid of roads and of railways, export was usually by river drives. This restricted the exported timber to predominantly the least dense and most reliably floated species such as pine. On new farmland, where timber could not be shipped, felled trees and stumps were burned and the ashes were often shipped in barrels for potash fertilizer. As railways were installed, the pattern changed. Hemlock was used for railroad ties, and the rail system became a conduit for balks of dense hemlock and other timber. The burgeoning production of leather from cattle grazing on cleared lands also prompted use of hemlock for tanbark. Meanwhile, milled hemlock found ready markets as immigrant housing demand increased in eastern North America. In the early $20^{\text {th }}$ century, there was also a large market for chestnut (Castanea dentata) (often salvaged from forests suffering chestnut blight) and maple. Finally, the 1898 and 1900 embargoes on the export of sawlogs and pulpwood to the
USA stimulated growth of industrial forest harvesting in Ontario, but mainly to the north of the study area (Gosselin 1987), with a consequent harvesting of smaller conifer trees.

The low point in the expanse and state of Ontario forests came in the 1920s (Larson et al. 1999). By the early $20^{\text {th }}$ century, soil exhaustion and erosion had become such a problem in southern Ontario that the provincial government undertook massive reforestation programs on sandy soils, principally using pines. When the problem soil areas had been addressed, reforestation tended to move into natural areas seen as needing rehabilitation. Some of these were, in fact, intact natural systems that have now been seriously compromised by ill-conceived tree planting. They include the pinery of southwest Ontario, the Constance Bay Sandhills in the Ottawa Valley and the prairie at Holland Landing on Lake Simcoe. They often represented the very last intact ecological systems of their regions and thus have lately become the focus of intense efforts at natural system restoration, including reintroduction of fire.

On the positive side, the concentration of agriculture on the best soils has allowed much secondary forest to spring up in southern Ontario, as elsewhere in eastern North America, and this young re-growth is rapidly maturing.

\section{Current Status of Old Growth in Southern Ontario}

Although there are other kinds of old growth in the north of the province, much of the focus on old-growth forest in Ontario since the 1980s has been on the pine forests of the Great Lakes forest biome (e.g., see the extensive literature lists in Carleton and Gordon 1992, Duchesne 1994, Jackson et al. 2000). Continued logging of formerly common old-growth red and eastern white pine forests on the Canadian Shield (Simard 2001) has engendered much concern among the conservation community (e.g., Ellis 1993, Kidd 1993, Quinby 1993, Anonymous 1994).

With their survey of largely upland heritage woodlands in southern Ontario, including old growth, Larson et al. (1999) redressed this imbalance focusing on central Ontario pine forests. They estimate that about $90 \%$ of the southern Ontario landbase was forested before European settlement. Currently, about $6 \%$ of the landbase is "original woodland," having continuity to presettlement times, and only a trace is old growth (Table 1). The replacement woodlands that were cleared at some point constitute about two thirds of total forested land, and the remaining $80 \%$ of the landbase is now non-forested. Larson et al. (1999) selected examples of high-quality heritage woodland on the basis of 15 characteristics (with sub-characteristics also), of which at least eight relate to old-growth character. However, among the descriptions of these selected 35 heritage sites, only six had the "old growth" epithet in the text.

Larson et al. (1999) did not date the original forest stands that they examined, except where they had existing data, so further estimates of the age of the forest estate are useful. The most universally available data are those of the 1978 Ontario Forest Resource Inventory (FRI), which is best regarded as a synoptic tool, as its accuracy for individual stands has often been questioned. The FRI illustrates how little forest exists that is greater than 100 years since stand origin (Table. 2). Of forests of over 100 years, virtually none predates the massive clearances of the $19^{\text {th }}$ century (Fig. 2), and much of the forest of over 120 years that has potential to become old growth (Fig 3) is direct- 
Table 1. Areas occupied in 1986 by categories of modern woodland in southern Ontario south of the Precambrian Shield (after Larson et al. 1999)

\begin{tabular}{|c|c|c|c|}
\hline \multicolumn{2}{|c|}{ Woodland Category } & \multirow{2}{*}{$\begin{array}{c}\begin{array}{c}\text { Area } \\
\text { Occupied } \\
\text { (ha) }\end{array} \\
\text { "Trace" }\end{array}$} & \multirow[t]{2}{*}{$\begin{array}{c}\text { Approximate } \\
\% \text { of } \\
\text { Ontario } \\
\text { Landbase } \\
\end{array}$} \\
\hline Original & Old Growth & & \\
\hline Woodlands & Older growth woodlands & 1 & \multirow{5}{*}{2} \\
\hline & Old Pioneer Woodlands & 1 & \\
\hline & & & \\
\hline Secondary & Working Woodlands & 4 & \\
\hline Woodlands & Replacement woodlands & 13 & \\
\hline Total Forested & & & 17 \\
\hline Non-forested & & & 81 \\
\hline Total & & & 100 \\
\hline
\end{tabular}

ly in the path of the massively expanding Greater Toronto metropolitan area. Indeed, areas documented in Fig. 3 and 4 have already fallen to urban sprawl. The very oldest forests of over 150 years (Fig. 4) are concentrated along the north shore of Lake Ontario on the Oak Ridges Moraine, on the Frontenac Arch of ancient shield rock along the St. Lawrence, and on the Awenda Peninsula at the south end of Georgian Bay. It should be noted that the FRI estimates the predominant age of dominant canopy species, and the forest may actually be older than this (Cumming et al. 2000).

Red and white pine working groups (Chapeskie 1989) together occupied only $5.3 \%$ of southern Ontario forests in the 1978 FRI (Table 2). Of the forests over 100 years old, only $3.3 \%$ were in the white pine working group, and there was no land in the red pine working group. In the forests of more than 150 years (only $1475 \mathrm{ha}$ ), the white pine working group occupied only 25 ha or $1.7 \%$. In contrast, the hemlock working group occupied 128 ha or $12.8 \%$. The maple working group, which (together with the hemlock working group) incorporates much of the old beech trees, was found on 188 ha or $12.8 \%$ of the area of over 150 years. Thus, hemlock, beech and maple stands are more common than pine-dominated stands, and this is even more apparent in the aggregate area of 150+ year stands. The process of transition from old-growth forest to such postsettlement forest has been addressed by White and Mladenoff (1994).
In addition to old southern Ontario stands in the FRI, there is a variety of other old ecological systems. Larson (2000) has documented gnarled old growth of eastern white-cedar (Thuja occidentalis) clinging to the cliffs of the Niagara escarpment and elsewhere, and these are possibly the oldest living trees in eastern North America. There are also systems of ancient origin that used to be frequently disturbed and that are, as a consequence, structurally open. They include the savannas of the Great Lakes sand dune systems, such as The Pinery on Lake Huron, oak savannahs as on Walpole Island, and alvar systems such as the Burnt Lands on the border between Lanark and Ottawa-Carleton counties. The work of Larson et al. (1999) shows that non-forested and semi-forested areas were common in southern Ontario, and the survey conducted by Gourlay for 1817-1819 (Gourlay 1974) demonstrates that many southwestern Ontario townships had widespread savannah and even prairie. One should also be aware of poorly documented wooded wetlands that have persisted more or less intact, and that may be of considerable age.

Thus, in contrast to much of the Great Lakes forest on the Shield in central Ontario, the remaining old forests of southern Ontario are not generally dominated by pines, and this raises a question: is the lack of old-growth pine forest in these regions primarily due to removal of pine by clearing, logging or perhaps postsettlement fire? Alternatively, or perhaps additively, was pine less common at the time of settlement than we have been led to believe? To answer these questions, we must investigate historical data.

\section{Tools for Knowing about Early Old-Growth Forests}

As old-growth forest in southern Ontario has virtually ceased to exist, the phytosociological and landscape ecological tools that might otherwise have been employed to define it (e.g., stump surveys - Simard 2001) are unusable. Moreover, the remaining fragments are probably atypical, and have been substantially modified by fire exclusion and other influences. In most cleared areas, not only have the old stumps burned or rotted, but also agriculture, housing and industry have even homogenized forest soil. Other than palynological evidence, all physical traces of the original forest have disappeared over most of the region. Nevertheless, we can use historical ecological

\begin{tabular}{|c|c|c|c|c|c|c|c|c|}
\hline Working Group & $\begin{array}{c}\text { Total } \\
\text { Forest } \\
\text { (ha) }\end{array}$ & $\begin{array}{c}\% \text { of } \\
\text { total forest } \\
\text { area }\end{array}$ & $\begin{array}{c}>100 \text { years } \\
\text { (ha) }\end{array}$ & $\begin{array}{c}>120 \text { years } \\
\text { (ha) }\end{array}$ & $\begin{array}{c}>150 \text { years } \\
\text { (ha) }\end{array}$ & $\begin{array}{l}\% \text { of }>100 \\
\text { year area }\end{array}$ & $\begin{array}{l}\% \text { of }>120 \\
\text { year area }\end{array}$ & $\begin{array}{l}\% \text { of }>150 \\
\text { year area }\end{array}$ \\
\hline Balsam fir (Bf) & 10934 & 0.6 & 0 & 0 & 0 & 0.0 & 0.0 & 0.0 \\
\hline White birch (Bw) & 42398 & 2.2 & 106 & 4 & 0 & 0.3 & 0.0 & 0.0 \\
\hline Hemlock (He) & 16595 & 0.9 & 2011 & 621 & 188 & 5.8 & 5.7 & 12.8 \\
\hline Hard maple (Mh) & 699527 & 36.2 & 18013 & 6841 & 633 & 52.3 & 62.7 & 42.9 \\
\hline Other conifer $(\mathrm{Oc})$ & 449131 & 23.3 & 7525 & 1837 & 336 & 21.8 & 16.8 & 22.8 \\
\hline Other hardwood (Oh) & 307849 & 15.9 & 5378 & 1336 & 286 & 15.6 & 12.3 & 19.4 \\
\hline Jack pine $(\mathrm{Pj})$ & 28512 & 1.5 & 0 & 0 & 0 & 0.0 & 0.0 & 0.0 \\
\hline Poplar (Po) & 250178 & 13.0 & 60 & 0 & 0 & 0.2 & 0.0 & 0.0 \\
\hline Red pine (Pr) & 43653 & 2.3 & 15 & 0 & 0 & 0.0 & 0.0 & 0.0 \\
\hline Scots pine (Ps) & 8 & 0.0 & 0 & 0 & 0 & 0.0 & 0.0 & 0.0 \\
\hline White pine (Pw) & 57567 & 3.0 & 1139 & 219 & 25 & 3.3 & 2.0 & 1.7 \\
\hline Black spruce (Sb) & 19138 & 1.0 & 20 & 2 & 0 & 0.1 & 0.0 & 0.0 \\
\hline Yellow birch (Yb) & 5042 & 0.3 & 180 & 46 & 6 & 0.5 & 0.4 & 0.4 \\
\hline Total & 1930542 & 100.0 & 34447 & 10906 & 1475 & 100.00 & 100.00 & 100.0 \\
\hline
\end{tabular}




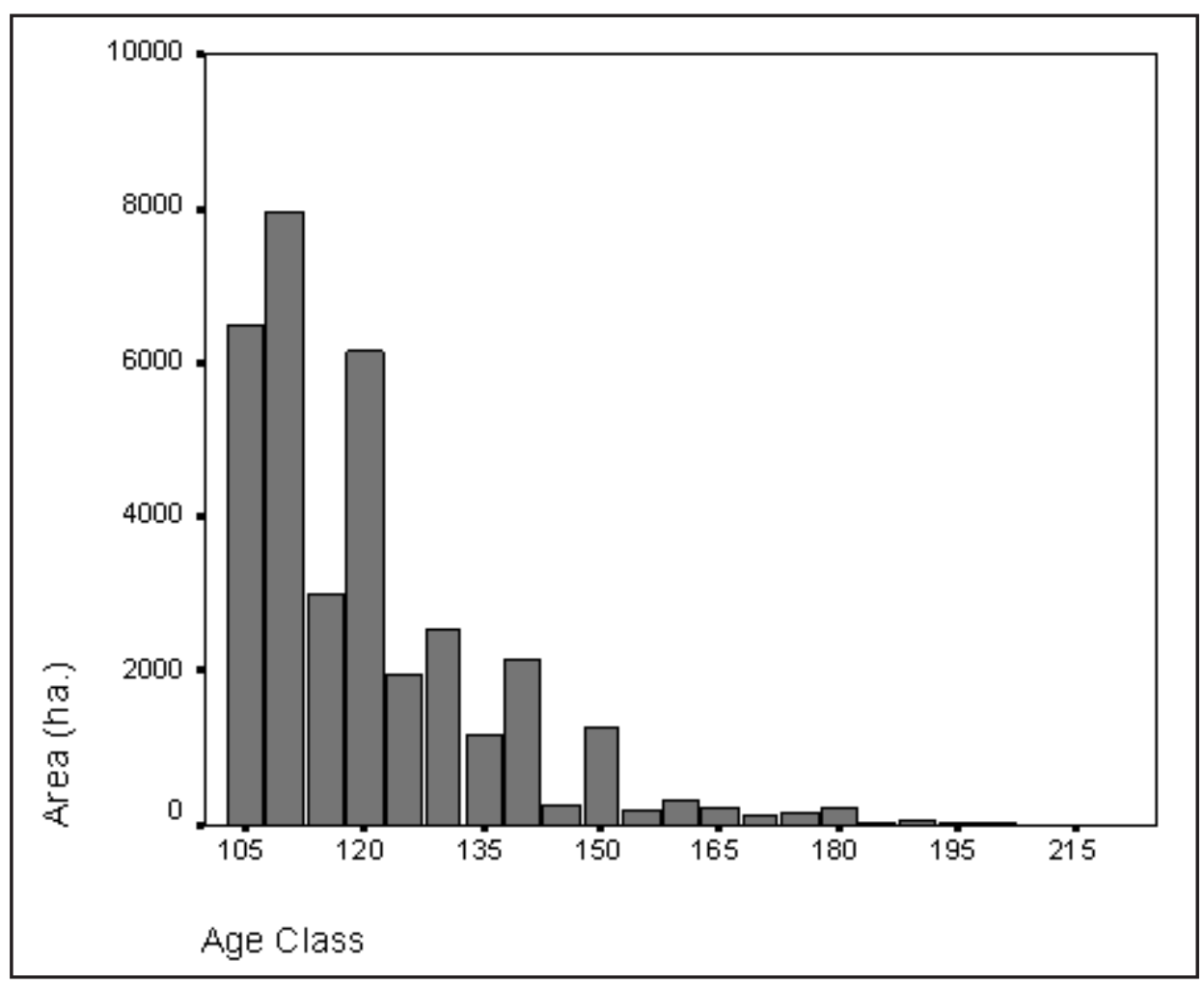

Fig. 2. Age class distribution $(>100$ years) in southern Ontario (ca. 1978).

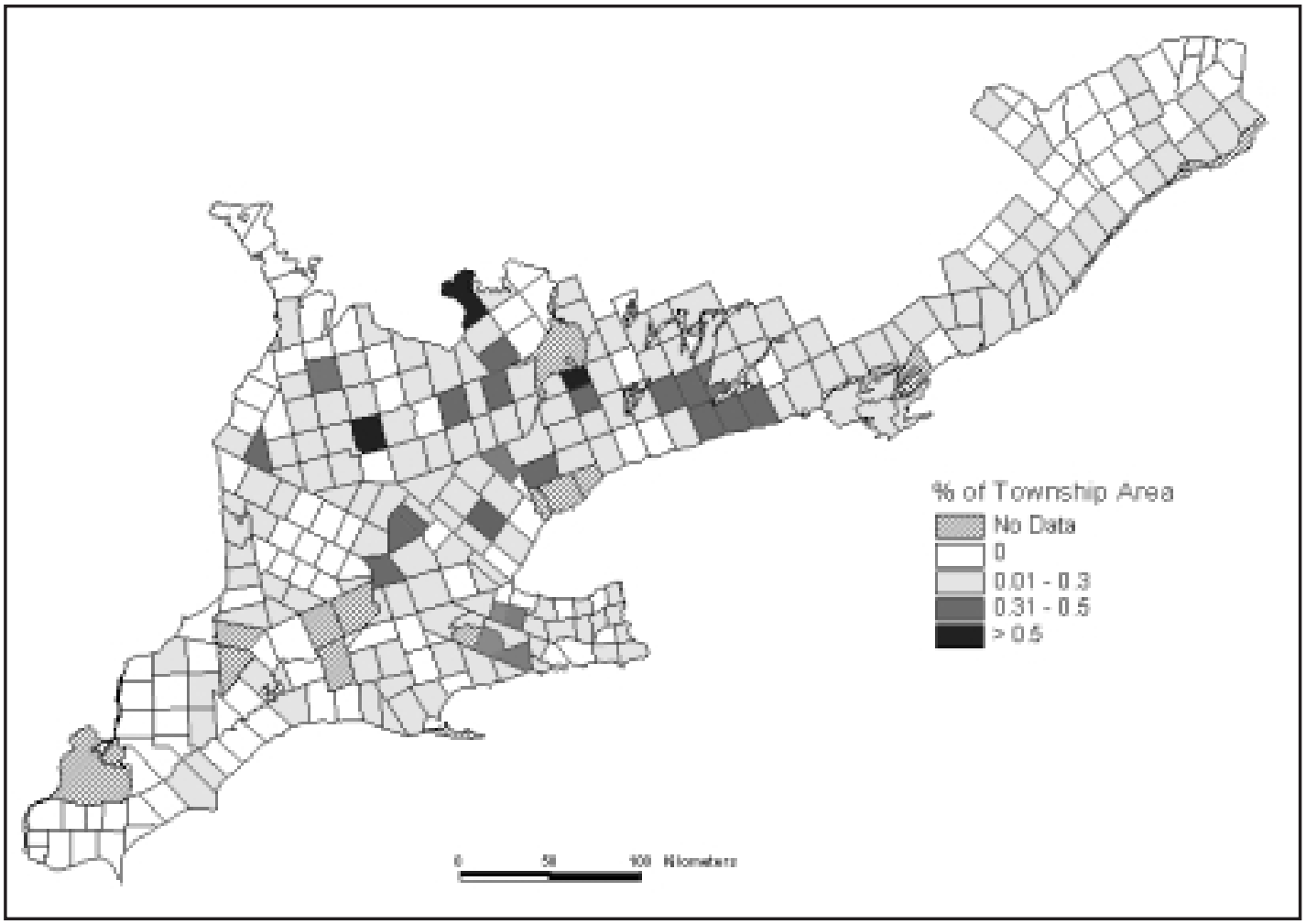

Fig. 3. Old forest in southern Ontario > 120 years (ca. 1978).

tools to discern the nature of the old landscape, and these have been explored in detail in Egan and Howell (2001). The usefulness of various methodologies in the old-growth context is summarized in Table 3.

As surveyors' records have been used in both the detailed case studies below, they require more specific comment. Sur- veyors were literate, numerate and had some (often informal) background in science. They marked out the land to be settled in each township, usually in transects that defined road allowances. They were encouraged to note the presence of tree species, so, with a good survey notebook, a relatively precise location and partial species list for each segment of each 


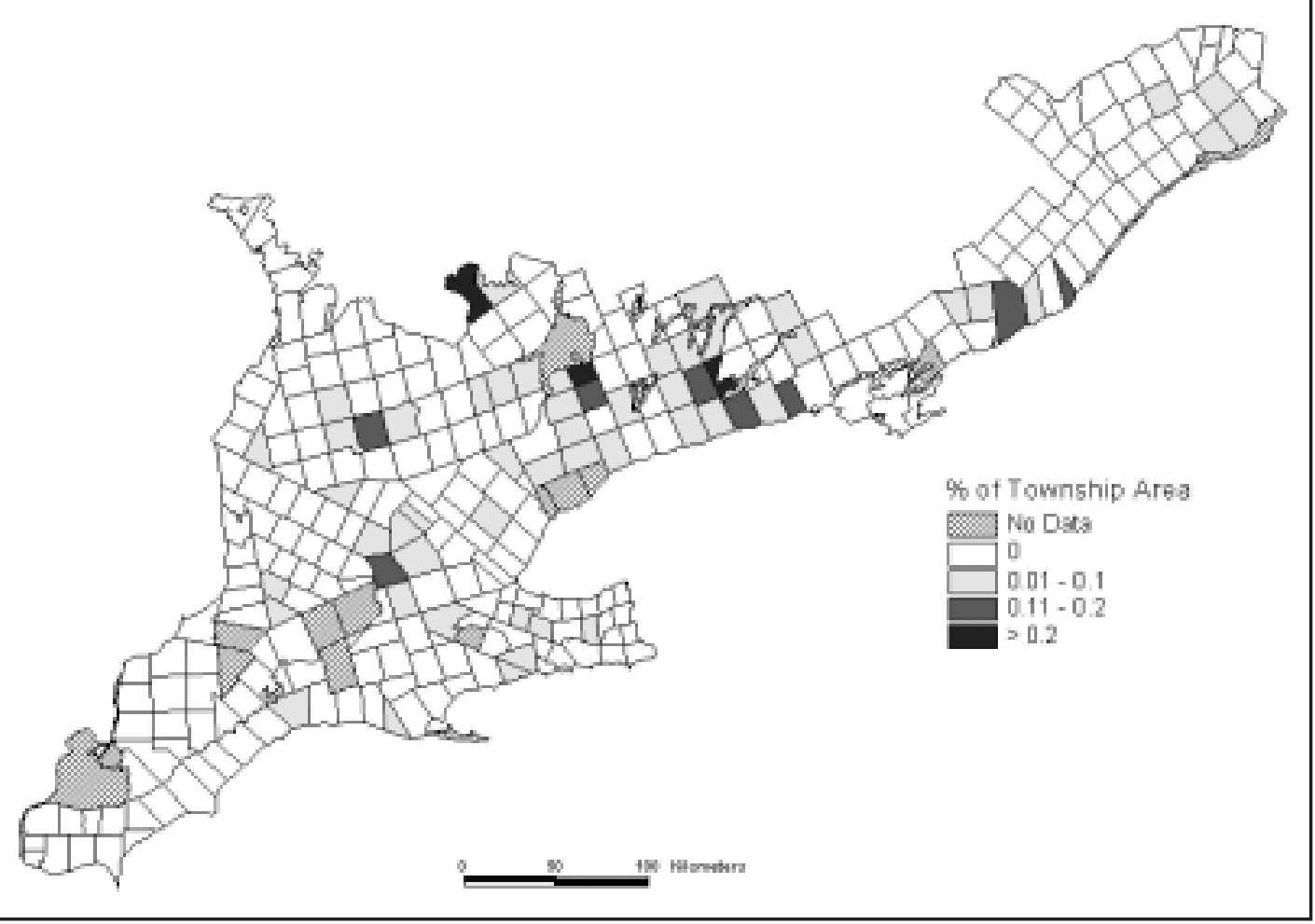

Fig. 4. Old forest in southern Ontario > 150 years (ca. 1978).

line can be found. Gentilcore and Donkin (1973) have suggested that the order in which tree species were cited usually corresponded to their dominance in that part of the landscape. On the other hand, trees unimportant to loggers and settlers may not have been noted, and the diligence and skill of surveyors varied. General approaches to survey records are found in Egan and Howell (2001) and methods specific to Ontario in Pile (1969), Gentilcore and Donkin (1973), Keddy (1993), and Elliot and Shiels (1994). One should note that surveyors in Ontario generally reported fewer details of vegetation than those in the USA, so American methodologies do not apply completely to Ontario (Gentilcore and Donkin 1973).

In general, historical information must be used judiciously because of biases associated with detecting and recording tree species, lack of error estimates of prediction, and problems of gross spatial extrapolation. The advantages of such historical approaches and some of their limitations are explored in the following case studies relating to forest changes due to logging and agriculture.

\section{Context of the Case Studies}

We selected two cases illustrative of typical settlement-era landscapes, and these are supplemented by information from Gourlay's early $19^{\text {th }}$ century statistical survey of southern Ontario (Gourlay 1974). The first case concerns the first survey of Darling Township in eastern Ontario, and the second covers the Bruce Peninsula National Park (BPNP) and its environs. Darling, on the edge of the Precambrian Shield, is representative of areas that were primarily exploited for logging, with settlement as a secondary activity on the better land. The Bruce Peninsula study represents an area of thin limestone soils that was first exploited by loggers and then turned over to hapless farmers who were obliged to deplete the soil. Much of the logging was done by companies, and much later than in Darling, so county-wide production records exist to cast further light on the historical vegetation. The Gourlay survey covers mostly good land in the process of intensive settlement for agriculture.

Darling Township is on the boundary of the St. Lawrence and Nipissing Ecoregions (Wickware and Rubec 1989), while the Bruce Peninsula study is in the Hurontario Ecoregion. The Gourlay survey covers the Erie Ecoregion with some outlying townships in Hurontario and St. Lawrence. Although the study areas thus exemplify every ecoregion of southern Ontario, they do not encompass all of the considerable physiographic and ecological variety within each of these regions.

\section{Darling Township \\ Selection of Study Area}

Darling was selected from about 60 townships in the Eastern Ontario Model Forest (EOMF), first on availability of historical survey information, second on how well each township represented the physiography of the EOMF, and third on the township's importance to current forest management in the Model Forest. Darling was surveyed before settlers and loggers arrived and also had existing GIS-based data (Elliott and Shiels 1994). The historical data were compared with the latest FRI data available at the time of the study, from 1960.

\section{Study Area}

Darling Township lies on the Precambrian Shield in Lanark County to the southwest of Ottawa in area L.4c of the Great Lakes-St. Lawrence Forest Region (Rowe 1972). It is characterized by rolling, irregular topography, with intermittent, shallow glacial deposits on the hills, and deeper ones in the valleys. The 
Table 3. Non-phytosociological information sources for historical forest conditions

\begin{tabular}{|c|c|c|}
\hline Information Source & Advantages & Limitations \\
\hline Artwork & $\begin{array}{l}\text { - Visual representation of structure } \\
\text { - Possible to identify individual species and } \\
\text { locations, as well as dates }\end{array}$ & $\begin{array}{l}\text { - Tendency to follow conventions of artist's birth } \\
\text { culture. } \\
\text { - Tendency to portray only what "ought" to be in the } \\
\text { landscape (art market opportunities, stereotypes, etc.) }\end{array}$ \\
\hline Photographs & $\begin{array}{l}\text { - Accurate visual representation of forest structure } \\
\text { and species } \\
\text { - Possible to identify individual locations and }\end{array}$ & $\begin{array}{l}\text { - Photographers' tendency to pick out "best" (atypical) } \\
\text { subjects except where forest is only a background to } \\
\text { a main subject }\end{array}$ \\
\hline
\end{tabular}

Written accounts

Palynology

Stump fences and rail fences

Stumps and $\operatorname{logs}$

Records of trade etc. - Licenses, invoices, government statistics, etc.

Surveyor's records

Place names (including towns, regions, road names, etc.)

Hudson Bay Company Records
A - Standing trees

- Exact location and species and sometimes date

- Ecological influences on wood structure can be deduced

B - Dead trees in lakes and wetlands

- See comments under (a)

- Often excellent preservation

- Objective species ID (sometimes only to species group)

- Representation of community composition (but must correct for pollen frequency)

- Ecological dynamics over time can be inferred

- Usually of local origin

- Species can be identified

- Possible to use dendrochronology

- Precise location and size

- Order of death can be inferred from layering on forest floor

- Quantitative record and exact date are common

- Some trade records differentiate species and timber sizes

- Approximate or precise locations (e.g. witness trees)

- Can be related to modern maps

- Often good species lists

Sometimes ancillary information

- Easily accessed

- Often synoptic for original vegetation

- Rich archive, well catalogued, including letters, diaries, reports, account books, maps, pictures
- Tendency to interpret vegetation in terms of previous experience and culture

- Confusion over old/local species names

- Need to evaluate information vis-à-vis writer's skills, honesty and biases

- Hardly ever available in the southern Ontario old-growth context

- Bias to lake shore vegetation-not typical of whole landscape

- Tends to be best at representing a region, watershed, etc. rather than a specific location

- No means of identifying mature forest except by circular inference

- Stump fences are rapidly disappearing

- Only certain species and sizes used

- Some species rot faster than others

- Tendency to move fences in recent years for heritage/aesthetic purposes

- Species rot at differential rates, and some material removed for use.

- Dating and species identification difficult or impossible

- Imprecise locations in almost all cases

- Species grouped and/or species names old

- Market forces bias the species recorded

- Incentives to misrepresent quantities (tax evasion, etc.)

- Imprecise/old species names

- Quality of record varies (evaluate at start of study)

- Bias to economic species and soil indicators

- May post-date first timber extraction

- Generally no record of size of trees

- Place names change - some historical research necessary

- Place names may be symbolic, e.g., Maple, Ontario

- Native names may be so old as to name vegetation under prehistoric climates

- Few records from south of Ottawa River

- Focus is not on vegetation - records have to be constructed from proxy information like amount of firewood gathering dominant upland forest species are sugar maple, beech, yellow birch (Betula alleghaniensis), red maple (Acer rubrum) and eastern hemlock, accompanied by eastern white pine and red pine. Other species include white spruce (Picea glauca), jack pine, trembling aspen (Populus tremuloides), white birch
(Betula papyrifera), red oak (Quercus rubra) and basswood (Tilia americana). Swampy areas are dominated by eastern whitecedar, black ash (Fraxinus nigra), black spruce (Picea mariana), tamarack (Larix laricina), red maple and, formerly, by white elm (Ulmus americana). 
The Ojibwa and Iroquois hunted in the area, and it first came under European land-use influence with the construction of the nearby Rideau Canal in 1826-1832 (Anonymous 1970). Land near the waterways was settled first, and the farmers felled and burned the trees to prepare farmland and produce potash fertilizer. By 1861, 17 townships in the EOMF had less than $30 \%$ forest cover and, by 1881, this rose to 32 townships (Kelly 1974, cited in Keddy 1993). By the early $20^{\text {th }}$ century, all the better soils had probably been cleared, but this trend reversed in the second half of the century as many farms were converted to conifer plantations, or reverted to bush.

The logging history of the EOMF is well-documented (Whitton 1942; Hughson and Bond 1964; McGill 1968; Head 1975, 1980; McCalla 1968; Keddy 1993). Trees were felled, squared and skidded to watercourses in winter, and floated out in spring for export to Europe. In 1840, the square timbers passing through the Chaudière Falls in Ottawa from the upper Ottawa valley, including Darling Township, were tallied as follows: 13 192 pieces of eastern white pine, 2130 of red pine, 3292 of oak and 1573 of elm (Head 1975). Although pine predominated, almost a quarter was of other species. As early as 1840, timber stands were thinning as northern Lanark County was impoverished of all valuable timber (Anonymous 1970). Square-timber logging used the relatively few large trees in a stand (Simard 2001), whereas later logging for sawn lumber employed most of what was found in a mixed age or relatively mature forest (Head 1975).

Guyette and Dey (1995), studying a mixed coniferous-deciduous forest near Darling Township, found that presettlement fires burned at low intensity with an average return interval of 26 years. Stand-replacing fires occurred about every 200 years, which is consistent with Heinselman's (1981) findings for xeric sites in the Lake States. Lumbering was often accompanied by wildfires fuelled by slash, and this may have been the case in Darling. Keddy (1993) noted three major fires in the EOMF between 1870 and the early 1900s, and the large fire of 1870 burned through the township. Howe (1915) demonstrated that the number of species and density of trees in a portion of nearby Peterborough County decreased with increased fire intensity. Poplar, red pine, jack pine and red oak all increased with fires, as did eastern white pine.

\section{Methods}

Land survey data collected in 1822 by William Kilbourn were transcribed from notebooks by T. Stephenson, digitized in ARC/INFO and converted into Thiessen Polygons by Elliott and Shiels (1994), and further analysed by Evans (1997). The 1960 FRI data were digitized as reported by Evans (1997). Kilbourn's tree species data were ranked according to the reporting order at each site, and the forest communities were classified using the TWINSPAN algorithm (Hill 1979, Gauch 1981). The 1960 FRI data were modified to be equivalent to the survey data by ranking the order of species' basal areas for each stand, and a similar TWINSPAN analysis was completed. The classifications developed were applied to the mapped 1822 survey and 1960 FRI data so as to produce comparable vegetation type maps. Areas in each vegetation type were tabulated from the two GIS layers. Further details of these methods are in Evans (1997).

\section{Findings}

Five broad classes were identified that conform to both the 1822 and 1960 classifications (Table 4). They show that the
Table 4. 1822-1960 changes in vegetation class areas in Darling township

\begin{tabular}{lcccc}
\hline $\begin{array}{l}\text { Composite } \\
\text { Class }\end{array}$ & $\begin{array}{c}\mathbf{1 8 2 2} \\
\text { Area }\left(\mathbf{k m}^{\mathbf{2}}\right)\end{array}$ & $\begin{array}{c}\mathbf{1 8 2 2} \\
\text { \% Area }\end{array}$ & $\begin{array}{c}\mathbf{1 9 6 0} \\
\text { Area }\left(\mathbf{k m}^{\mathbf{2}}\right)\end{array}$ & $\begin{array}{c}\mathbf{1 9 6 0} \\
\text { \% } \text { Area }^{\mathbf{a}}\end{array}$ \\
\hline Lowland & 86.8 & 33.5 & 51.8 & 18.0 \\
Coniferous & 0.0 & 0.0 & 0.1 & $<<1.0$ \\
Deciduous & 1.3 & $<1.0$ & 79.6 & 28.5 \\
Mixed & 143.8 & 53.5 & 91.5 & 35.0 \\
Other & 36.1 & 13.0 & 44.8 & 19.5
\end{tabular}

${ }^{a}$ Average of point-in-polygon and polygon-in-polygon methods.

Table 5. 1822-1960 changes in stand dominant areas in Darling township

\begin{tabular}{lcccc}
\hline $\begin{array}{l}\text { Dominant } \\
\text { Species }\end{array}$ & $\begin{array}{c}\mathbf{1 8 2 2} \\
\text { Area }\left(\mathbf{k m}^{\mathbf{2}}\right)\end{array}$ & $\begin{array}{c}\mathbf{1 8 2 2} \\
\text { \% } \mathbf{~ T w p . ~}\end{array}$ & $\begin{array}{c}\mathbf{1 9 6 0} \\
\text { Area }\left(\mathbf{k m}^{\mathbf{2}}\right)\end{array}$ & $\begin{array}{c}\mathbf{1 9 6 0} \\
\text { \% } \mathbf{~ T w p . ~}^{\mathbf{a}}\end{array}$ \\
\hline Tamarack & 29.4 & 11.5 & 0.0 & 0.0 \\
Willow & 0.1 & $<1.0$ & 0.0 & 0.0 \\
Spruce & 27.5 & 10.0 & 0.2 & $<1.0$ \\
Balsam Fir & 0.0 & 0.0 & 1.3 & $<1.0$ \\
Black Ash & 8.7 & 3.0 & 0.0 & 0.0 \\
Hemlock & 51.0 & 19.5 & 0.0 & 0.0 \\
Hemlock-Pine & 0.0 & 0.0 & 0.1 & $<<1.0$ \\
Pine & 0.0 & 0.0 & 43.3 & 15.5 \\
White Cedar & 0.0 & 0.0 & 2.0 & $<1.0$ \\
Elm & 0.0 & 0.0 & 46.2 & 17.5 \\
Elm-basswood & 4.2 & 1.5 & 0.0 & 0.0 \\
Butternut & 0.3 & $<<1.0$ & 0.0 & 0.0 \\
Ironwood & 1.0 & $<1.0$ & 0.0 & 0.0 \\
Male & 77.4 & 27.5 & 79.2 & 28.0 \\
Maple-basswood & 0.0 & 0.0 & 04 & $<1.0$ \\
Birch & 2.5 & 1.5 & 0.0 & 0.0 \\
TOTAL & & + & 124.5 & + \\
\hline
\end{tabular}

a Average of point-in-polygon and polygon-in polygon methods

+ percentages as do not add to 100 because of unidentified, unclassified or unvegetated areas with no dominants indicated

area of lowlands (wet, organic soils) in the township has been reduced from $32 \%$ of the area to $19 \%$. The deciduous forest component has risen from less than $1 \%$ to about $30 \%$, and the mixed forest has declined from above $50 \%$ to about $35 \%$. Nonforested land has increased.

Turning to stand dominants (Table 5), hemlock dominated half the township in 1822 and all these lands have all been converted to other types. Similarly, spruce and tamarack, occupying $10 \%$ each in 1822, have been decimated. Elm forests have been reduced by Dutch elm disease in the mid $20^{\text {th }}$ century, but mapledominated stands held their own at about $30 \%$ of the area. Although pine was dominant on $16 \%$ of the area in 1960 , it did not show anywhere as a dominant in 1822 . Therefore, the biggest change in the forest of this area was the virtual elimination of hemlock old forest, not the removal of pine.

The Darling case study tells us about the net changes in the areas of forest dominants, but offers little about the big trees of the square-timber trade that are a useful focus of oldgrowth studies. The next example, dating from a better-documented period later in the $19^{\text {th }}$ Century, yields more information in this regard.

\section{The Bruce Peninsula National Park Study Area}

The 154-km² Bruce Peninsula National Park lies at the tip of a long north-south limestone peninsula fringed on the west by coastal fens along Lake Huron. Eastward, the land rises almost imperceptibly to the Niagara escarpment cliffs that plunge into 
Georgian Bay. The Park interior is characterized by shallow limestone soils interspersed with open, flowery alvars. Today, most of the park supports only scrubby forest of eastern whitecedar, fir (Abies balsamea) and red and jack pines. Neighbouring areas outside the park that have deeper soils have mostly been converted to cattle pastures. The area lies within Rowe's forest area L. 1 in the Great Lakes-St. Lawrence region (Rowe 1972), but the northern two townships of the Peninsula have much pine-dominated forest relative to the rest. This distribution of conifer and deciduous forest on the Bruce has persisted over long time periods, as noted by Bennett (1993).

Lindsay and St. Edmunds Townships, the present-day park and its environs, were first surveyed in 1855 . The area was almost all well-forested, with beech-maple and hemlock forest on relatively deep soils, as well as where there are alvars with deep fissures. In 1855, much of the Park supported extensive eastern white-cedar, poplar and white birch forest. These stands were interspersed with pine forests dominated by red, jack and some eastern white pine.

European exploitation began in the 1870s with extensive timber licenses corresponding to the pine area and, by 1883, virtually all mature pine had been logged. In 1883, after a change in government policy, agricultural settlers quickly occupied the lands with deeper soils, and their clearance activity also generated much timber for sale. By 1900, the lands suitable for farming had been settled and the original timber supply had been exhausted except for less valuable species like eastern whitecedar. On the alvars, slash piles left by loggers intensified escaped fires from farm clearance activities elsewhere, and repeated ground fires damaged the thin, largely organic soils. These fires were probably more frequent and more intense than had been the case under the natural fire regime. Recent decades have seen farms abandoned on all but the deepest soils and the forest is slowly returning to most of the area.

\section{Methods}

The 1855 survey was digitized in a SPANS GIS database. For each concession (length of road allowance between two intersections), species were ranked in the order in which they appeared in the survey notes. Each concession was classified as to vegetation type using TWINSPAN. As the number of data cases (concessions) far exceeded the capacity of the software, they were first sorted, using EXCEL, to find identical cases, of which only one of each set was used in TWINSPAN analysis. Imprecise 1855 identities were clarified through a series of protocols assigning them to specific species or to groups of species (Suffling et al. 1995).

The most suitable modern "snapshot," the FRI of 1978, which had been updated to 1981, was converted to a SPANS database. The dominant FRI species by basal area were mapped and compared with the dominants (first listed species) in the 1855 database. Further details of the methods are given in Suffling et al. (1995).

\section{Findings}

1855-Other, similar surveys of Bruce Peninsula townships from this era mention meadows, but the St. Edmunds/Lindsay survey does not, from which we infer that the upland landscape was largely closed forest. The TWINSPAN 1855 classification (Fig. 5) separated the forest into deciduous/mixed and conifer communities. The deciduous/mixed communities were divided, in turn, into permutations of maple, beech and hemlock. The maple-beech type had admixtures of eastern whitecedar that are indicative of rock outcrops. Judging from the modern forest, the maples are probably sugar and red maple mixtures. Beech was found with eastern hemlock, and many hemlock sites had a "pine" component (eastern white pine?). Beech and hemlock probably occurred on somewhat deeper, leached soils where the roots were not in direct contact with high $\mathrm{pH}$ limestone substrates (see Burns and Honkala 1990). Several small, distinctive areas were dominated by "oak" - probably red oak.

The 1855 conifer forests divided into those with admixtures of successional "poplar." Then there were balsam fir-eastern white-cedar mixtures, with black ash on wetter sites. The remainder - most of the area—was eastern white-cedar, which is today found on rocky sites and in swamps. Other eastern whitecedar areas had admixtures of "pine" and "birch." In these cases, individual species were not mentioned but we can infer from modern analogies on the Bruce that eastern white, red and jack pine were all present.

Tamarack (Larix laricina) is found today, not only in the usual fen habitats, but is also scattered across shallow limestone soils. Because of this wide ecological amplitude and the lack of truly quantitative data, tamarack confused the TWINSPAN classification process, and had to be omitted. Thus, a tamarack fen community should be appended to the TWINSPAN classification.

We infer from the above that pines were dominant in just three communities and they were a minor component in some hemlock-maple, beech and eastern white-cedar communities. Pines were largely absent from other communities in the survey.

The map of 1855 vegetation uses the TWINSPAN classification, and can be divided (Fig. 6) into three broad zones: 1) From C30 to V22 eastward, and from C14 to I14 westward, maple-beech forests are associated with deeper soils. 2) A rocky area with alvars extends from C30 to V22 west to a line from C14 to I14. This area had cedar communities with some pine as well as some pine-dominant communities. As this area was the focus of early, intense pine logging for square timber, there must have been huge pines with a cedar understorey. The light-dependent cedar community implies scattered pines over much of the area. 1981 - The Bruce Peninsula study area was divided into the same broad zones as above. However, the zone east of C30 to V22 (Fig 7) is dominated by maple rather than maple-beech and hemlock, and this reflects both the current phase of forest re-establishment following farm abandonment, and the previous removal of beech and hemlock. Elsewhere in this zone, white birch and poplar are taking over the abandoned pastures.

In the central Zone, westwards from the above to a line from C14 to I14, cedar is dominant with some areas of pine, as in 1855. However, there are no large pines. Poplar and birch dominate parts of this zone in the aftermath of logging and fire. In the area west of $\mathrm{C} 14$ to I14, poplar and birch are dominant, reflecting more recent agricultural abandonment compared to areas further east. As in 1855, cedar and fir are the dominants at the tip of the Peninsula. John Galt described similar "not very lofty" vegetation here in 1827 (Wake 1997). A few tiny areas of red oak (not visible on Fig. 7) correlate strongly with ancient sand dunes.

Changes in stand dominants from 1855 to $1981-\mathrm{Hem}$ lock forest that formerly dominated in $41 \%$ of the area has been 


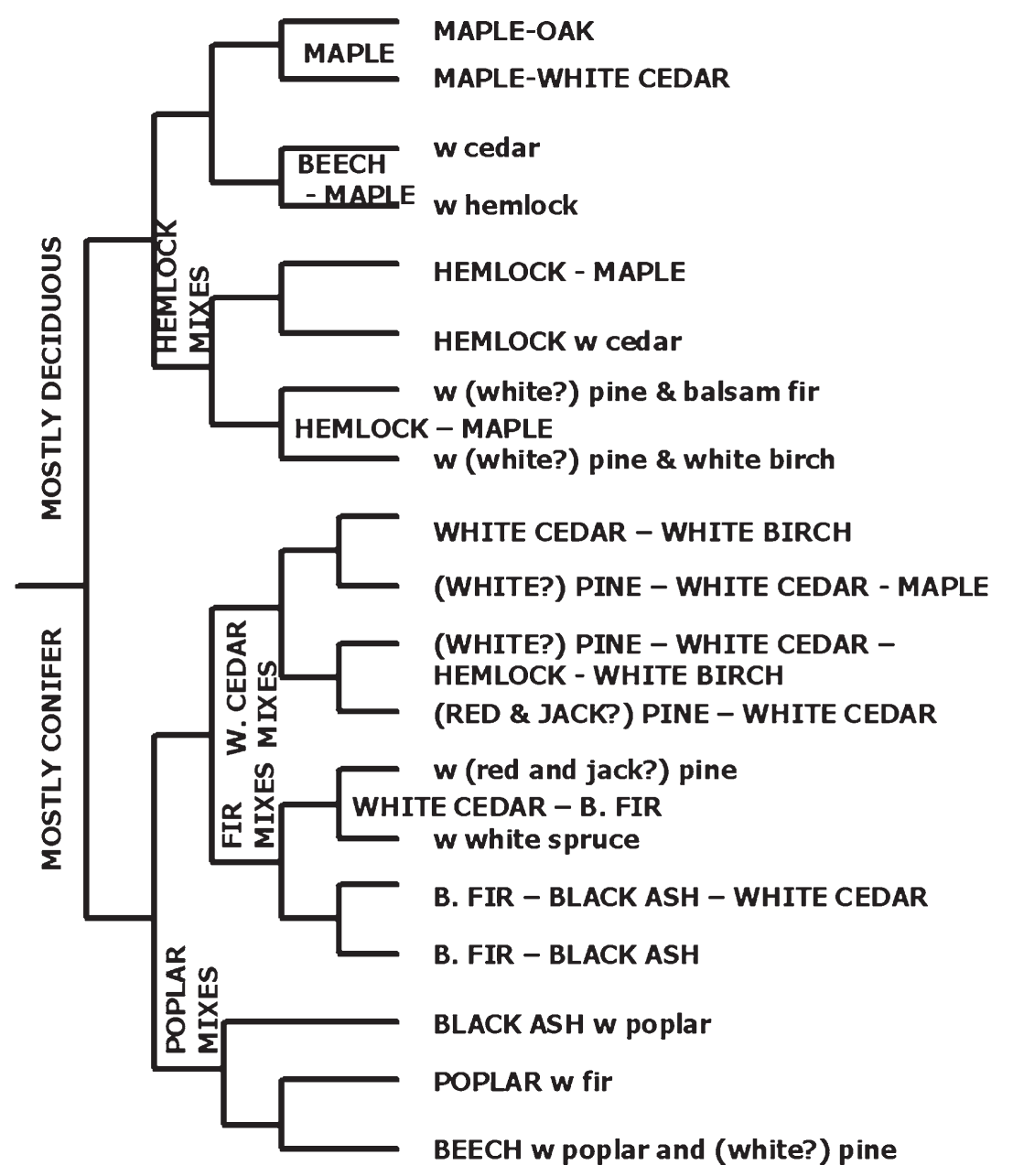

Fig. 5. TWINSPAN classification of 1855 forests in St. Edmunds and Lindsay townships.

virtually eliminated (Table 6). Likewise, beech stands on deep soil sites in 1855 have all but disappeared under the influence of agriculture and grazing. The tamarack communities have also been drastically reduced. Former beech and hemlock areas now occupied by abandoned fields are succeeding to white birch, poplar species and (mostly red) maples.

The pine community on shallow limestone soils (dominant in $13 \%$ of the area in 1855) has been reduced in area, first by logging and then by repeated fires that removed seed sources. The pine component has been replaced by an early succession of eastern white-cedar, white birch and poplar (primarily trembling aspen and largetooth aspen (Populus grandidenta$t a)$ ). The destruction of pine communities has not been as complete as for hemlock and beech, but tree stature and ecosystem structure have been reduced within the remaining pinery.

Of the species that were stand dominants on small areas in 1855, white ash, elm and fir have all been reduced in area. Fir is now an exceedingly common understorey, but is not normally a stand dominant, and this reflects a 1960s spruce budworm outbreak that removed older firs. Red oak is restricted to old sand dunes in the modern system, but in 1855 it was more widespread. We speculate but have been unable to prove that red oak stands were fire savannas.
Where were the big trees? Huge quantities of square timber were exported from the Peninsula, and there were virtually no old forests left in the study area in 1981 (except cliff and alvar eastern white-cedars). Lumbering in St Edmunds (the location of the pinery) was vastly heavier than in any other township in Bruce County (Robertson 1971). The Cook Brothers Company dominated square-timber extraction until 1881, and their timber licenses approximated the extent of pine in the 1855 survey. The British Canadian Lumber Company, which bought the licenses in 1881, was also most active in $\mathrm{St}$ Edmunds Township and, like its predecessor, was legally restricted to pine harvesting. By 1884, the large pines had all been taken, and British Canadian collapsed. We may conclude that most Bruce County pine harvest before 1884 came from St Edmunds Township.

Complementary evidence comes from fragmentary production statistics. Pine square-timber production from St. Edmunds (Anonymous no date) in 1881-1883 was 7170 pieces. At a minimum of two pieces per big tree, this represents 1195 trees per year. As volumes of these timbers are given, too, one can calculate average square-timber sizes, which were 1.38 , 1.14 and $1.11 \mathrm{~m}^{3}(48.9,40.6$, and $39.5 \mathrm{cu}$. ft. $)$ in $1881-1883$, respectively. The shrinking piece size foreshadows the 1884 


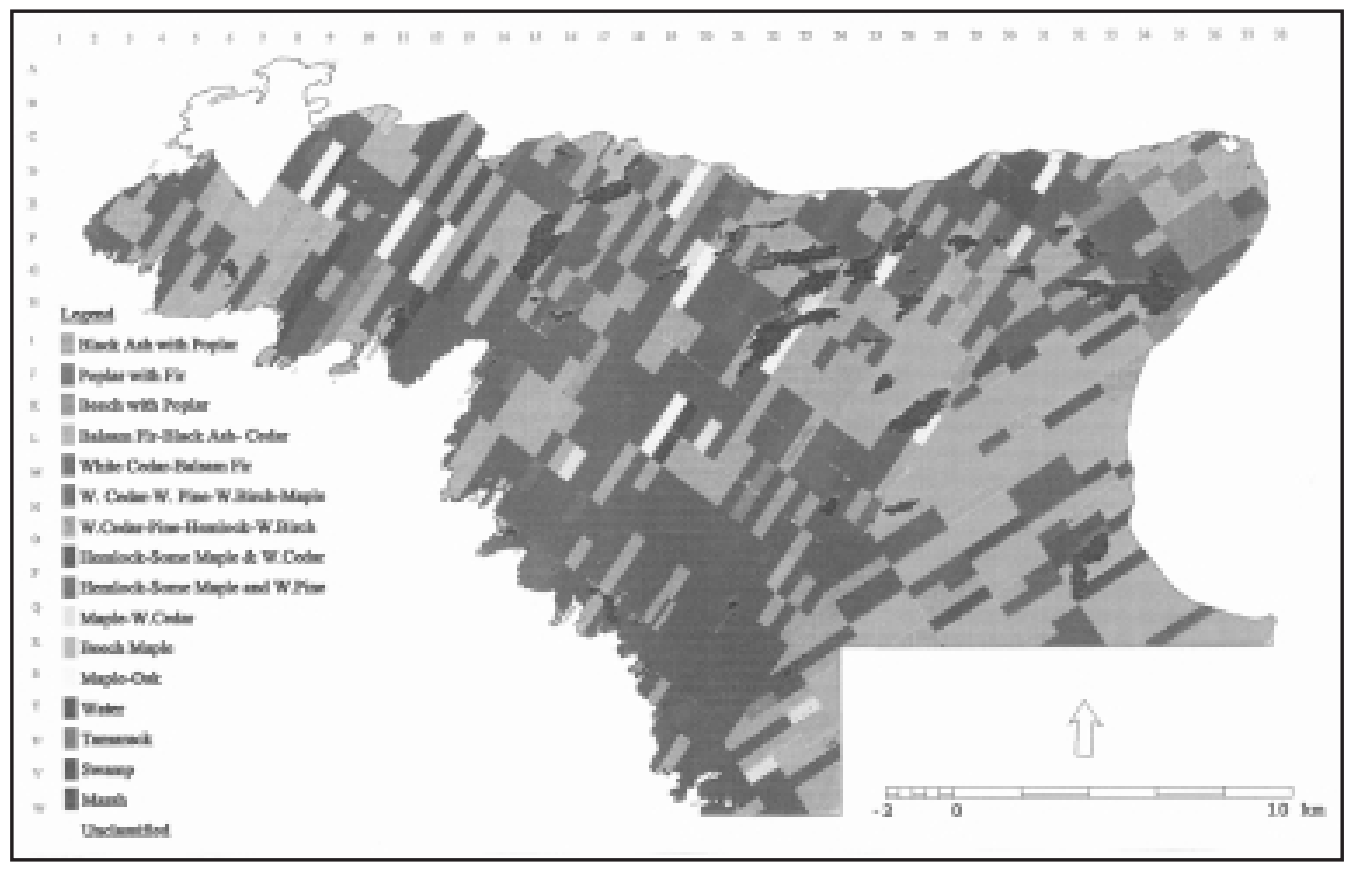

Fig. 6. TWINSPAN categories of 1855 Forests in St. Edmunds and Lindsay townships.

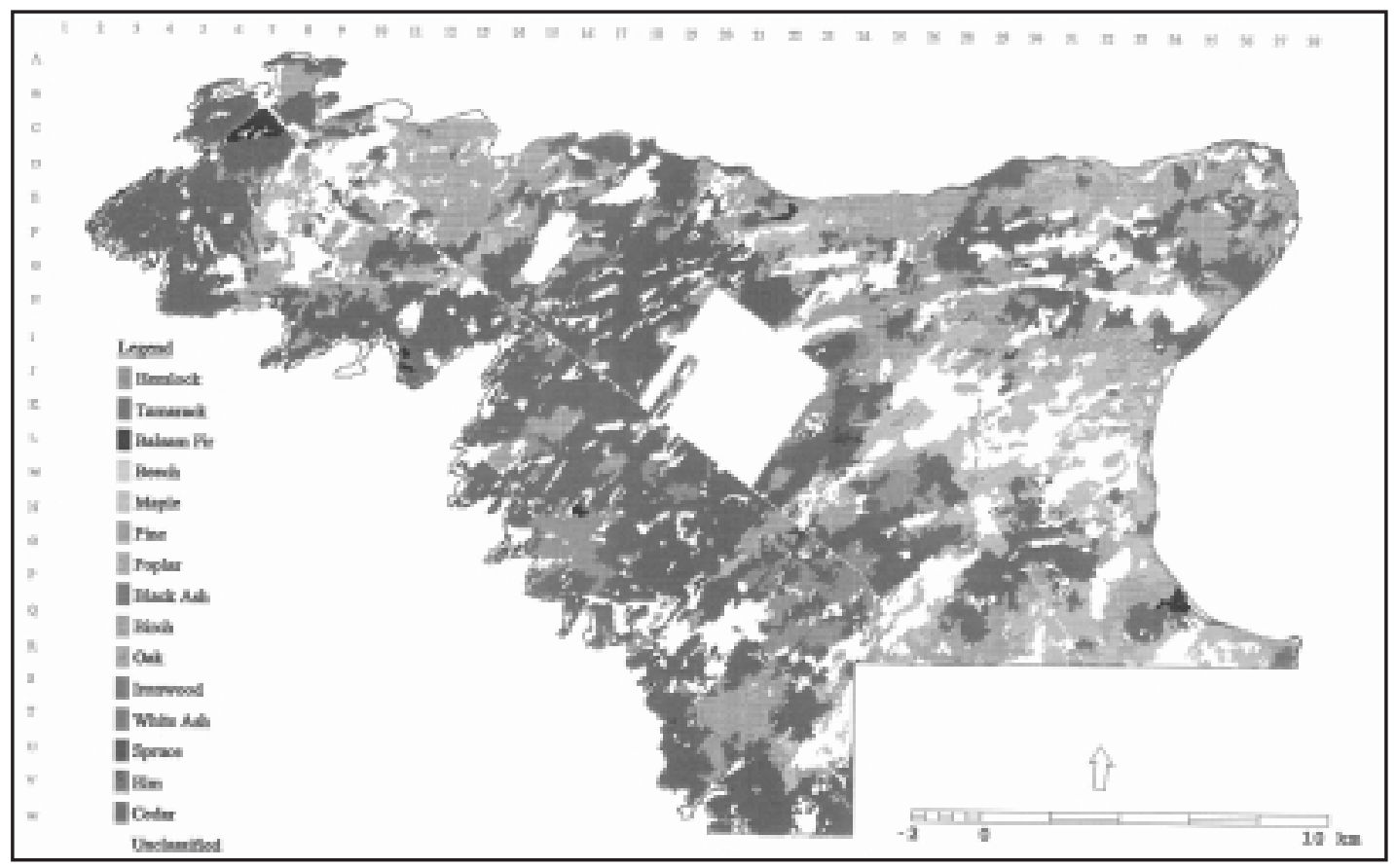

Fig. 7. 1981 Forest dominants in St. Edmunds and Lindsay townships.

collapse of the pine square-timber trade in St. Edmunds. Unfortunately, the pine square-timber production figures for Bruce County as a whole are only available for 1880 (Ontario Conservation Authorities Board 1962), in which they are $3051 \mathrm{~m}^{3}$ (108299 cu ft), or about 2230 pieces using the 1881 conversion above. When 97 masts and spars are added (one per tree), the total is about 2320 trees. Therefore, the St. Edmunds figures represent somewhere between 50 and $100 \%$ of the total production for the county, of which St. Edmunds $\left(257 \mathrm{~km}^{2}\right)$ represents only $8.2 \%$. Thus, large pine trees must have been very scattered indeed in the whole of the rest of the county.

Pine square-timber production, available at 10-year intervals for the whole of Bruce County (Ontario Conservation Author- ities Board 1962), demonstrates (Fig. 8) that huge volumes of elm and "other" non-pine squared timber were shipped. By elimination, "other" can be deduced to be mostly hemlock and maple. Lumber companies built massive chutes onto the side of the escarpment down which the great timbers could be tipped, and then loaded into schooners. Even elsewhere in the county, distances to the Lake Huron shore were short, so the densest timber could be readily shipped. Furthermore, these non-pine square timbers were shipped after the 1883 administrative changes permitting settlement, and after the collapse of the British Canadian Lumber Co., so they must have come largely from the deep soil areas of the Peninsula. Therefore, the trade statistics show not only that big pines were rare in Bruce County woods 
Table 6. 1855-1981 changes in stand dominant areas in St. Edmunds and Lindsay Townships

\begin{tabular}{lcccc}
\hline & $\begin{array}{c}\mathbf{1 8 5 5} \\
\text { Area }\left(\mathbf{k m}^{\mathbf{2}}\right)\end{array}$ & $\begin{array}{c}\mathbf{1 8 5 5} \\
\text { \% Area }\end{array}$ & $\begin{array}{c}\mathbf{1 9 8 1} \\
\text { Area }\left(\mathbf{k m}^{\mathbf{2}}\right)\end{array}$ & $\begin{array}{c}\mathbf{1 9 8 1} \\
\text { \% Area }\end{array}$ \\
\hline Hemlock & 142.2 & 41 & 0.0 & 0 \\
Beech & 82.9 & 24 & 0.0 & 0 \\
Tamarack & 27.4 & 8 & 0.0 & 0 \\
Black ash & 6.3 & 2 & 0.0 & 0 \\
Oak & 3.9 & 1 & 0.1 & $<<1$ \\
Balsam fir & 6.3 & 2 & 1.6 & $<1$ \\
Pine & 44.3 & 13 & 14.2 & 4 \\
Maple & 27.4 & 8 & 34.0 & 9 \\
Spruce & 0.4 & $<1$ & 0.4 & $<1$ \\
Poplar & 1.0 & $<1$ & 43.0 & 11 \\
Birch & 5.7 & 2 & 45.9 & 12 \\
Non-forested & 0.0 & 0 & 96.5 & 24 \\
White cedar & 0.0 & 0 & 159.8 & 40 \\
Study area total & 337.6 & $101^{1}$ & 395.4 & 100 \\
\hline TColumato & & & &
\end{tabular}

${ }^{1}$ Columns do not total exactly 100 because of rounding errors.

outside the St. Edmunds pinery, but also that other kinds of large trees such as hemlock, maple and elm were common.

\section{The Gourlay Survey of 1817-1819}

We have used two cases from southern Ontario to characterize the settlement-era forests, but are these findings representative of the whole area? To repeat such studies for every township might take many decades, so we must look to general sources to find typical conditions, but in less detail. Robert Gourlay's work provides an excellent resource. During 1817-1819, this fiery political activist sent a land-use survey questionnaire to settlers in each township. He asked a question about the dominant vegetation, especially the tree species, asking for them in decreasing order of occurrence. From the returns, we can map the vegetation (Fig 9). The primeval forest in 1819 settled southern Ontario was dominated by pines in tightly defined areas, mostly on sandy soils. These totalled less than half the townships along Lakes Ontario and Erie and less than half the reporting area. Conversely, oak forests and savannahs were relatively common. However, the new capital of Toronto was virtually surrounded by a large pinery, and this probably coloured the vegetation perceptions of generations of politicians, civil servants and teachers.

\section{Discussion and Conclusions}

Pines in general — and eastern white pine in particular-hold peculiar sway over perceptions of forests in Ontario (Aird 1985), so much so that eastern white pine has been designated as the Provincial Tree. The place of eastern white pine is assured by its beauty, by its ultimate huge size, and by its romantic image from the square-timber logging era. In addition, scientific and conservation information from central Ontario shows that the conifers in general, and pine in particular, have been very common but have been greatly reduced by harvesting to the benefit of shade-tolerant hardwoods (Leadbitter 2001, Simard 2001). But how much large pine habitat existed in reality in southern Ontario?

Data presented here demonstrate that present-day old and oldgrowth forests in southern Ontario do not include a high proportion of pine stands. However, pines tend to grow on soils that are less favourable to agriculture, and a number of the old pineries have thus persisted. They include the Pinery Provincial Park, St. Edmunds in the Bruce Peninsula, and much of Simcoe County (Heidenreich 1973). In such areas, the average size of the pines has been much reduced, first by square-timber logging, then by logging for milled timber and also by frequent fires during the logging era. Huge volumes of squared pine timber came from these limited areas. Thus, removal of other forest types from land more suited to agriculture has possibly increased the proportion of pines in the remaining forest in southern Ontario-but only if pine was originally uncommon elsewhere.

By looking at areas outside today's pineries, we can see whether pine-dominated forests were common, and if pine was a large component of other forests. This was not the case in Darling Township on the Precambrian Shield and, beyond the well-defined St. Edmunds pinery, it was not the case on the limestone of the Bruce Peninsula. Similarly, Heidenreich (1973) has demonstrated for Simcoe County that pines were the only tree species to form pure stands, and that other species associated with pines only in a minority of cases. Szeicz and Macdonald (1991) demonstrated, for Haldimand-Norfolk, Brant, Elgin and part of Waterloo that presettlement pine forests were restricted to less than one quarter of the area. Davis' historical work (Davis 1987, Moss and Davis 1994) on Victoria County, Wellesley Township in Waterloo, and Wainfleet in Niagara showed that

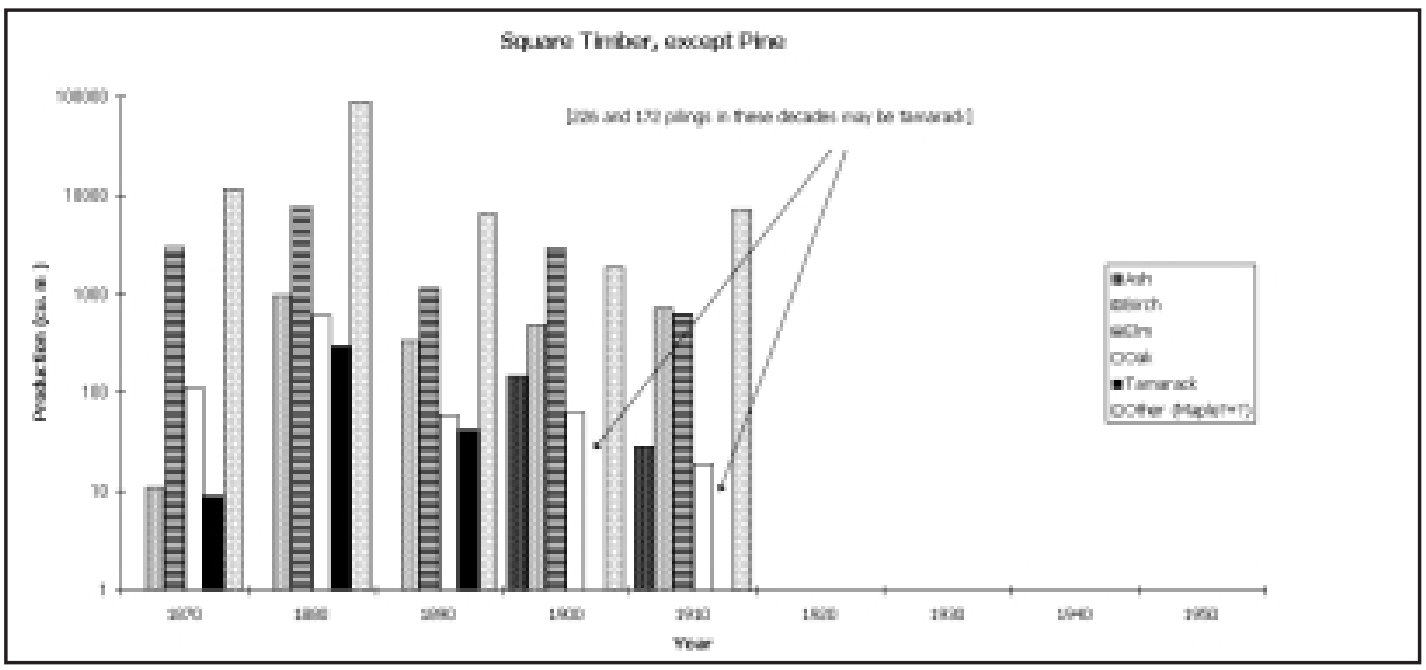

Fig. 8. Annual Bruce County square-timber production at 10 year intervals in 1870,1880 , etc (after Ontario Conservation Authorities Branch 1962). 


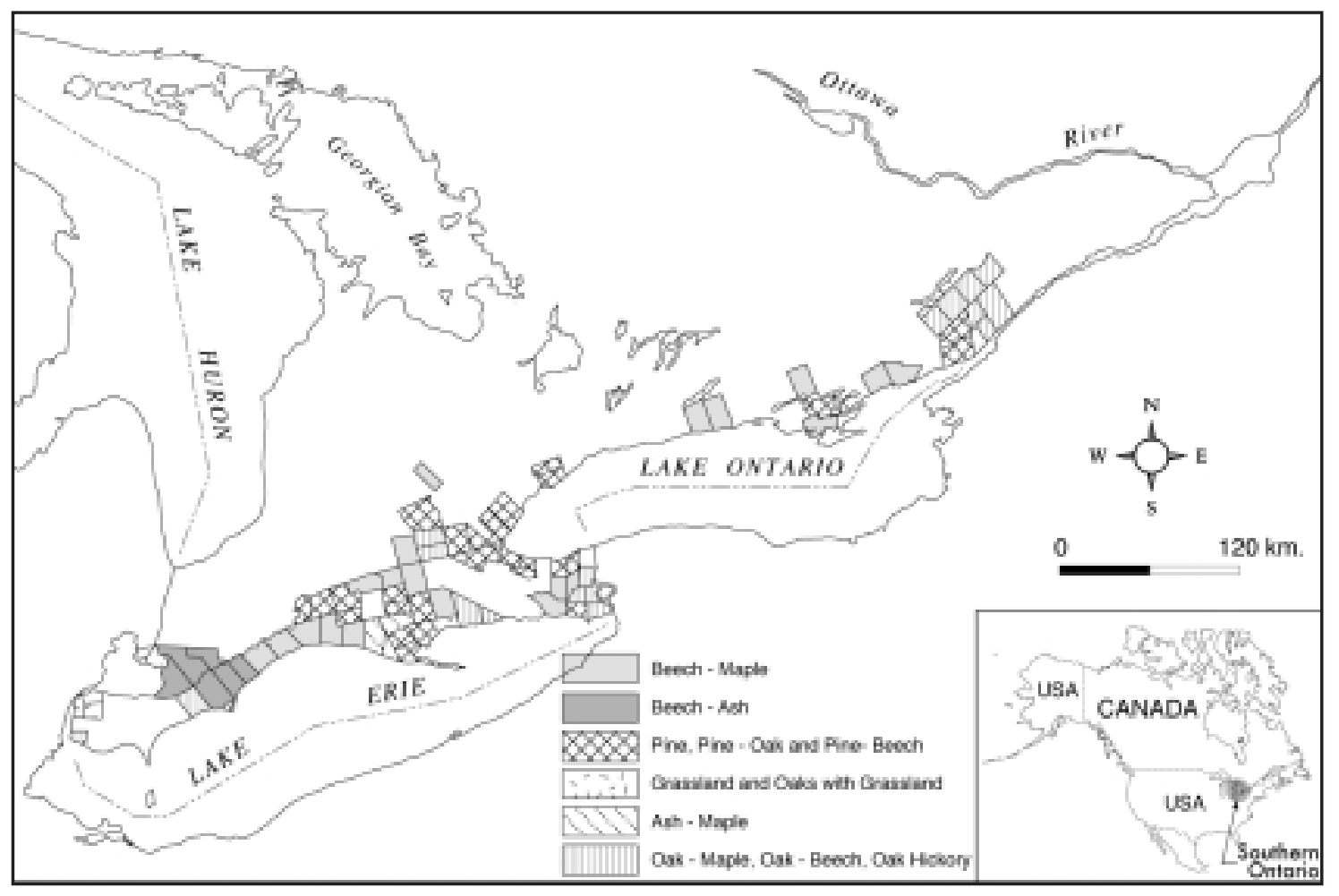

Fig. 9. Dominant tree species by township as reported in the 1817-1819 Gourlay survey.

pine was not particularly common in these areas either. And throughout the far south, Gourlay's survey (Gourlay 1974) shows more beech-maple and oak-dominated townships than pinedominated ones. Even within several of Gourlay townships, where pine was reported dominant, hardwoods in fact dominated much of the area (Wood 1961, Wilcox 2000).

What was the situation in the neighbouring Great Lakes States and New England? Cogbill's (1996) work on Maine, and Vermont demonstrates that pine occurred in survey "witness trees" no more than in $2 \%$ of cases. Frelich and Reich (1996), working in Minnesota and northern Michigan, see eastern white pine as a "minor but important" component of the northern hardwood-hemlock forest. Conversely, they identify eastern white pine with a red pine component as a separate type (corresponding with the Ontario pineries reported here), intermediate in fire disturbance between the classic mixed pine forests of the north and the hemlock-hardwood stands predominating further south. Abrams' (2001) extensive survey of previous studies in the northeastern USA reaches the same conclusion. If widely separated groups of pines began life on sites disturbed by very infrequent fires or on scattered windstorm tracks, this is exactly the spatial pattern to be expected. Only on fire-prone sites — sandy soil and rocks - would pine achieve dominance at a landscape level or even, perhaps in individual stands.

The size of at least a proportion of the pines is demonstrated by the square-timber pine trade, but were there large, old trees apart from the pines? Evidently, there were, and they were part of the timber trade where they could be exported, as in the Bruce Peninsula, and as demonstrated by the timber passing the
Chaudière Falls in Ottawa. These observations corroborate findings obtained by different methods and in other places in the USA by Abrams (2001).

We recall the big pines because of the pine square-timber trade, but other species that were just as common in southern Ontario, or more so, tend to not to be remembered. They were marketed in a more forgettable form. Hemlock was decimated by clearance for agriculture, by harvesting for lumber after the arrival of the railways, by potash production and by tanbark collection. The failure of hemlock to recolonize has been attributed to larger deer populations (Whitney 1984, Anderson 1992), but Mladenoff and Stearns (1993) suggest a multi-faceted explanation. Similarly, the less valuable beech was cleared from the richer soil areas and shipped as potash. It too has failed to reestablish over large areas, and this has been blamed on beech bark disease (Cryptococcus fagisuga and Nectria spp.) in New England (Houston 1994).

What does this mean for restoration policies? First, because there is so little old ( $>150$ years) forest left in southern Ontario, mature stands, and especially original stands should be preserved through vigorous conservation efforts that address pressures for land development as well as ill-advised commercial timber exploitation. Among such older stands, specific examples should be selected and managed to mature into old- growth forest. Second, on relatively firefree sites, over most of southern Ontario, the fairly complete clearance of hemlock and beech forest should be systematically redressed by restoration efforts. Because beech especially is not a favoured commercial species, new methods of restoration and conservation management may need to be devised. 
Third, presettlement pine forests in southern Ontario occurred primarily on sandy and rocky areas experiencing relatively frequent fires, and attempts at restoration to presettlement condition should recognize this, as at the Pinery Provincial Park. Where reintroduction of fire is limited by housing, commercial forestry or other land uses, decisions must be made as to whether to allow new kinds of forest to continue to develop, or whether to test and possibly adopt surrogate practices to mimic fire effects.

As we enter an era in which there is a desire to regenerate samples of old-growth forests, we must understand the true nature of the original forests. These findings run counter to historical tradition and the cultural icon that Ontarians have made of eastern white pine. We should remember, moreover, that the observed historical trajectory is just one of a number of scenarios that might have happened had any major climatic, human or biological variable been just a little different in nature or in timing (Boychuk and Perera 1997). Thus, in examining any historical information for scientific or management purposes, we should be acutely aware of the cultural, economic and emotional prisms through which we receive information. Some, no doubt, will reason that historical records are impossibly subjective and fallible, but to ignore this wealth of material just because it is not universally rigorous is to bypass what is often the most immediate and vibrant record.

\section{Acknowledgements}

We gratefully acknowledge the financial and logistical support of Parks Canada, Natural Resources Canada, and the Eastern Ontario Model Forest; and the support and encouragement of Ian Thompson, Luc Duchesne, Eric Boysen, Brian Barkley, Grant Head and Scott Parker. We are grateful for permission to use the data of Barbara Elliott and B. Shiels.

\section{References}

Abrams, M. 2001. Eastern white pine versatility in the presettlement forest. Bioscience 51: 967-979.

Aird, P.L. 1985. In praise of pine: the eastern white pine and red pine timber harvest from Ontario's crown forest. Canadian Forestry Service, Petawawa National Forestry Institute, Chalk River, Ontario. Report PI-X-52.

Anderson, 1992. Hemlock: its ecology and management. In B. Naylor and L. Thompson (eds.). Regenerating conifer cover in deer yards. pp. 62-86. Central Ontario Forest Technology Development Unit Technical Report No. 28. North Bay. Ontario Ministry of Natural Resource and Environment Canada. 117 p.

Anonymous. No date. Land and timber transactions, Wiarton office 1878-1881. Vol. 1031. Unpublished document. Ontario Archives P.A.C. RG 10.

Anonymous. 1970. Mississippi Valley conservation report: history. Ontario Department of Energy and Resources Management. Anonymous. 1990. Old-growth forests... what are they? How do they work? Proceedings of a Symposium held at the University of Toronto, Jan $20^{\text {th }}$ 1990. Canadian Scholars Press, Toronto, Ontario. $197 \mathrm{p}$. Anonymous. 1994. Interim report on conserving old growth forests. Ontario Old Growth Forests Policy Advisory Committee. Queen's Printer for Ontario, Toronto, Ontario. 32 p.

Anonymous. 1996. The old-growth forests of southern Ontario. Ontario Extension Note LRC 26. Ontario, Queens Printer for Ontario. Toronto, Ontario.

Bennett, K.D. 1987. Holocene history of forest trees in southern Ontario. Canadian Journal of Botany 65: 1792-1801.

Bennett, K.D. 1993. Holocene history of forest trees on the Bruce Peninsula, southern Ontario. Canadian Journal of Botany 70: 6-18.
Boychuk, D. and A.H. Perera. 1997. Modeling temporal variability of boreal landscape age classes under different fire disturbance regimes and spatial scales. Canadian Journal of Forest Research 27: 1083-1094

Braithwaite, M. and R.S. Lambert. 1957. We live in Ontario. The Book Society of Canada Ltd., Agincourt, Ontario. 256 p.

Bryant, D.G. 1997. The last frontier forests: ecosystems and economies on the edge. World Resources Institute, Washington, D.C. $42 \mathrm{p}$.

Burdon, E.T., J.H. McAndrews and G. Norris. 1986. Palynology of Indian and European forest clearance and farming in lake sediment cores from Awenda Provincial Park, Ontario. Canadian Journal of Earth Sciences 23: 43-54.

Burns, R.M. and B.H. Honkala. 1990. Silvics of the forest trees of North America: Volume 1, Conifers. Volume 2, Hardwoods. US Department of Agriculture, Forest Service. Washington, D.C.

Campbell, I.D. and J.H. McAndrews. 1993. Forest disequilibrium caused by rapid Little Ice Age cooling. Nature 366: 336-338.

Carleton, T.J. and A.M. Gordon. 1992. Understanding old-growth red and white pine-dominated forests in Ontario. Ontario Forest Research Institute. Report Number 2. Sault Ste. Marie, Ontario. 81 p.

Chapeskie, D.J. 1989. A silvicultural guide for the white pine and red pine working groups in Ontario. Queen's Printer for Ontario, Toronto, Ontario. $102 \mathrm{p}$.

Cogbill, C.V. 1996. Black growth and fiddlebutts: The nature of oldgrowth red spruce. In M.B. Davis (ed.). Eastern old-growth forests: prospects for rediscovery and recovery. pp. 113-125. Island Press, Washington D.C.

Cooper, J.I. 1978. Ontario's first century: 1610-1713. Lawrence Lande Foundation, McGill University, Montreal, Quebec. 159 p.

Cumming, S.G., F.K.A. Schmiegelow and P.J. Burton. 2000. Gap dynamics in boreal aspen stands: is the forest older that we think? Ecological Applications 10: 744-759.

Davis, M.B., T.E. Parshall and J.B. Ferrari. 1996. In M.B. Davis (ed.). Eastern old-growth forests: prospects for rediscovery and recovery. pp. 291-304. Island Press, Washington, D.C.

Davis, S. 1987. Evolving landscape productivities in four rural townships of southern Ontario circa 1810-1980. Ph.D. Thesis, University of Waterloo. Ottawa, National Library of Canada (Microfiche). Day, R. 1990. The dynamic nature of Ontario's forests from postglacial times to the present day. In Old-growth forests.... what are they? How do they work? Proceedings of a Symposium held at the University of Toronto, Jan $20^{\text {th }} 1990$. pp. 63-122. Canadian Scholars Press, Toronto, Ontario. 197 p.

Delcourt, P. and H. Delcourt. 1987. Long-term forest dynamics of the temperate zone. Ecological Study \# 63. Springer Verlag. New York, N.Y. 439 p.

Duchesne, L.C. 1994. Defining Canada's old-growth forest problems and solutions. The Forestry Chronicle 70: 739-744.

Egan, D. and E.A. Howell (eds.). 2001. The historical ecology handbook: a restorationist's guide to reference ecosystems. Island Press for the Society for Ecological Restoration, Washington, D.C. 457 p. Elliott, B. and B. Shiels. 1994. The application of geographic information systems for the interpretation of historic land surveys. Eastern Ontario Model Forest. Information Report No. 8. Kemptville, Ontario.

Ellis, L. 1993. Canadian old-growth forests: a status report from Newfoundland to British Columbia. Canadian Parks and Wilderness Society, Ottawa, Ontario. 42 p.

Evans, M. 1997. Incorporating historical ecology into forest management planning. Unpublished MA Thesis. University of Waterloo, Waterloo, Ontario. 129 p.

Frelich, L.E. and Reich, P.B. 1996. Old growth in the Great Lakes Region. In M.B. Davis (ed.). Eastern old-growth forests: prospects for rediscovery and recovery. pp. 144-160. Island Press. Washington, D.C.

Gauch, H.G. 1981. Hierarchical classification of community data. Journal of Ecology 69: 135-152. 
Gentilcore, L. and K. Donkin. 1973. Land surveys in southern Ontario: an introduction and index to the field notebooks of the Ontario land surveyors 1784-1859. Supplement No. 2 to Canadian Cartographer $10.116 \mathrm{p}$.

Gosselin, C. 1987. Paved with good intentions: the long road to forest management and planning in Ontario 1882-1987. Unpublished MA Thesis. University of Waterloo. Waterloo, Ontario. 435 p.

Gourlay, R. 1974. Statistical account of Upper Canada, abridged (with introduction by S.R. Mealing). McLelland and Stewart, Toronto, Ontario. $395 \mathrm{p}$.

Guyette, R. and D. Dey. 1995. A presettlement fire history in an oak-pine forest near Basin Lake, Algonquin Park, Ontario. Ontario Forest Research Institute. Forest Research Information Paper No. 132. Sault Ste. Marie, Ontario.

Hasenstab, R.J. 1990. Agriculture, warfare, and tribalization in the Iroquois homeland of New York: a G.I.S. analysis of late woodland settlement. Ph.D. thesis, University of Massachusetts. Ann Arbor. UMI Dissertation Services. 385 p.

Head, C.G. 1975. An introduction to forest exploitation in nineteenth century Ontario. In. J.D. Wood (ed.). Perspectives on landscape and settlement in nineteenth century Ontario. pp. 78-112. McLelland and Stewart, Toronto, Ontario.

Heidenreich, C.E. 1970. The historical geography of Huronia in the first half of the seventeenth century. Unpublished Ph.D. dissertation. McMaster University. Hamilton, Ontario.

Heidenreich, C.E. 1973. A procedure for mapping the vegetation of northern Simcoe County from the Ontario land survey. In L. Gentilcore and K. Donkin (eds.). Land surveys in southern Ontario: an introduction and index to the field notebooks of the Ontario land surveyors 1784-1859. pp. 104-113. Supplement No. 2 to Canadian Cartographer $10.116 \mathrm{p}$.

Heinselman, M.L. 1981. Fire intensity and frequency as factors in the distribution and structure of northern ecosystems. In Fire regimes and ecosystem properties. pp. 7-57. USDA Forest Service General Technical Report WO-26.

Hill, M.O. 1979. TWINSPAN- a FORTRAN program for detrended correspondence analysis and reciprocal averaging. Cornell University Press, Ithaca, N.Y.

Houston, D.R. 1994. Major new tree disease epidemics: beech bark disease. Annual Review of Phytopathology 32: 75-87.

Howe, C.D. 1915. The effect of repeated fires upon reproduction of commercial species in Peterborough County, Ontario. In Forest protection in Canada 1913-1914. Commission of Conservation of Canada. William Briggs, Toronto, Ontario.

Hughson, J.W. and C.C.J. Bond. 1964. Hurling down the pine. The Historical Society of the Gatineau, Old Chelsea, Quebec.

Jackson, S.M., F. Pinto, J.R. Malcolm and E.R. Wilson. 2000. A comparison of European settlement (1857) and current (1981-1995) forest composition in Central Ontario. Canadian Journal of Forest Research 30: 605-612.

Keddy, C. 1993. Forest history of eastern Ontario (revised 1994) Eastern Ontario Model Forest Information Report No. 1. Kemptville, Ontario.

Kelly, K. 1974. The changing attitude of farmers to forest in nineteenth century Ontario. Ontario Geography 8: 64-77.

Kidd, J. 1993. Interim report on conserving Ontario's old growth red and white pine. Ontario Old Growth Forests Policy Advisory Committee. Queen's Printer for Ontario, Toronto, Ontario. 35 p.

Larson, B.M, J.L. Riley, E.A. Snell and H.G. Godschalk. 1999. The woodland heritage of southern Ontario: a study of ecological change, distribution and significance. Federation of Ontario Naturalists, Don Mills, Ontario. 262 p.

Larson, D.W. 2000. Cliff ecology: pattern and process in cliff ecosystems. Cambridge University Press, Cambridge. 340 p.

Leverett, R. 1996. Definitions and history. In M.B. Davis (ed.). Eastern old-growth forests: prospects for rediscovery and recovery. Island Press, Washington, D.C.
Leadbitter, P. 2001. A comparison of the pre-settlement and present diversity of the forests of central Ontario. Unpublished M.Sc. thesis. Lakehead University, Thunder Bay, Ontario. 75 p.

McAndrews, J. H. 1994. Pollen diagrams for southern Ontario applied to archaeology. In R.I. MacDonald (ed.). Great Lakes archaeology and paleoecology: exploring interdisciplinary initiatives for the nineties: proceedings of a symposium. pp. 179-195. Quaternary Sciences Institute, University of Waterloo, Waterloo, Ontario.

McAndrews, J.H. 1988. Human disturbance of North American forests and grasslands: the fossil pollen record. In B. Huntley and T. Web III (eds.). Vegetation history. pp. 673-697. Handbook of Vegetation Science No. 7. Kluwer Academic Publishers. Dordrecht, The Netherlands. 803 p.

McAndrews, J.H. and M. Boyko-Diakonow. 1989. Pollen analysis of varved sediment at Crawford Lake, Ontario: evidence of Indian and European farming. pp. 528-530. Quaternary Geology of Canada and Greenland. Geological Survey of Canada, Geology of Canada, No. 1 .

McCall, D.L. 1991. Monty Python: a chronological listing of the troupe's creative output and articles and reviews about them. McFarland, Jefferson, N.C. 210 p.

McCalla, J. 1968. A forest products and Upper Canada development, 1815-1846. Canadian Historical Review LXVIII: 159-198.

McGill, J. 1968. A pioneer history of the county of Lanark. T.H. Best Printing Company, Toronto, Ontario.

Mladenoff, D.J. and V. Stearns. 1993. Eastern hemlock regeneration and deer browsing in the northern Great Lakes region: a re-examination and model simulation. Conservation Biology 7: 889-900.

Moss, M.R. and L.S. Davis. 1994. Measurement of spatial change in the forest component of the rural landscape of southern Ontario. Applied Geography 14: 214-231.

Ontario Conservation Authorities Branch. 1962. Sauble Valley conservation authority report. Queen's Printer, Toronto, Ontario.

Pile, D. 1969. Methods of analysing original vegetation cover using early land survey records. Unpublished MA thesis. McMaster University, Hamilton, Ontario.

Quinby, P.A. 1993. Ancient forest research report No. 1: protecting ancient forests on Ontario through timber management. http://www.ancientforest.org/rr1.html (accessed 30th May 2002).

Ritchie, J.C. 1987. Postglacial vegetation of Canada. Cambridge University Press, Cambridge. 178 p.

Robertson, N. 1971. The history of the County of Bruce and minor municipalities therein. Richardson, Bond and Wright, Owen Sound, Ontario. Rowe, J.S. 1972. Forest regions of Canada. Canadian Forest Service Publication 1300. Ottawa, Ontario. 172 p.

Simard, J.H. 2001. Habitat selection, ecological energetics, and the effects of changes in white pine forests on breeding red crossbills (Loxia curvirostra) in Algonquin Provincial Park, Ontario. Unpublished M.Sc. thesis. McGill University, Montreal, Quebec.

Snow, D.R. 1994. The Iroquois. Blackwell. Cambridge, Massachussetts. $268 \mathrm{p}$

Suffling, R., T. Clarke, M. Evans, L. Lamb, S. May, I. McKenzie and A. Ramunas. 1995. Vegetation change and vegetation management in the Bruce Peninsula National Park and environs. Final Report for Parks Canada Award No. 2379501. Faculty of Environmental Studies, University of Waterloo, Waterloo, Ontario. 135 p. Szeicz, J.M. and G.M. Macdonald. 1991. Postglacial vegetation history of oak savanna in southern Ontario. Canadian Journal of Botany 69: 1507-1519.

Wake, W. (Cairns) (ed.). 1997. A nature guide to Ontario. Federation of Ontario Naturalists, Toronto, Ontario. 469 p.

White, M.A. and D.J. Mladenoff. 1994. Old-growth forest landscape transitions from pre-European settlement to the present. Landscape Ecology 9: 191-205.

Whitney, G.C. 1984. Fifty years of change in the arboreal vegetation of Heart's Content, an old-growth hemlock-white pine hardwood stand. Ecology 65: 403-408. 
Whitton, C. 1942. A hundred years a fellin'. The Runge Press, Ottawa, Ontario.

Wickware, G. M. and C. D. Rubec. 1989. Ecoregions of Ontario.

Ecological Land Classification Series No. 26. Environment Canada, Sustainable Development Branch, Ottawa. 38 p.

Wilcox, K. 2000. Long Point Biosphere Reserve landscape change study. In Landscape change at Canada's biosphere reserves. Environment Canada. pp. 29-34. Toronto, Ontario. 56 p.
Wood, J.D. 1961. The Woodland-Oak Plains Transition Zone in the settlement of western Upper Canada. Canadian Geographer 1: 43-47. 